Gadjah Mada International Journal of Business

September-December 2007, Vol. 9, No. 3,pp. 409-453

\title{
BEHAVIOR OF STOCK PRICE VARIABILITY OVER TRADING AND NONTRADING PERIODS, AND DAILY RETURN VOLATILITY
}

\begin{abstract}
Sumiyana
This study examined the behavior of stock price variability over trading and nontrading periods, and daily return volatility. This study used intraday data in Indonesia Stock Exchange. Sample was taken from the firms listed in LQ 45 indexes for the year of 19992006. The behavior of stock price variability and daily return volatility, according to previous theories, is influenced by the array of public and private information.

This study concludes that return variance over trading and nontrading periods, along with overnight and lunch break nontrading session, and the first and second trading session, has differed significantly. In addition, daily return volatility is also not identical significantly. Subsequently, this study used size, trading volume, bidask spreads and up-down market as control variables. This study contradicts to all prior studies. This study especially suggests contra evidence in comparisons with previous concepts and theories in regards to size, trading volume, bid-ask spreads, and up-down market as control variables.
\end{abstract}

Keywords: behavior; bid-ask spread; Levene's F-test; intraday data; return; size; trading volume; up-down market; variability; volatility

JEL Classification: G-14; G-18

* I thank these names from the Faculty of Economics, Gadjah Mada University, who have given their contribution to this research: Jogiyanto Hartono, Suwardjono, Slamet Sugiri, Indra Wijaya K., Ertambang Nahartyo, Sony Warsono, and Eko Suwardi (as my adviser). This paper had been presented in The $8^{\text {th }}$ Annual Conference of The Asian Academic Accounting Association. I considerated to all suggestion from this conference that make this paper be better. 
Gadjah Mada International Journal of Business, September - December 2007, Vol. 9, No. 3

\section{Background}

The intraday stock availability has triggered empirical studies on stock price variability behavior over trading and nontrading periods, especially on the end of trading period, and daily return volatility. The end of trading period can be defined as the end of sessions or the end of days. Many studies have been conducted to investigate the stock return behavior based on intraday. The findings suggest that stock price has a tendency to increase systematically in the end of sessions or days (Harris 1986; Jain abd Joh 1988; Wood et al. 1985; Mcnish and Ord 1990).

Harris (1986) finds that stock price behavior increases in the end of trading period day. This study was done in NYSE for the 1981-1983 periods. Wood et al. (1985) used a wider analysis by using stock price per hour in NYSE and find the same result for the 1971-1972 and 1982 period. Then, Mcnish and Ord (1990) observed it again in NYSE for the 1980-1984 data, and used the same formula for stock price behavior. Jain and Joh (1988) also find the same result from investigating stock price change per hour in NYSE for the 1979-1983 data. Their studies conclude that:

1. Stock price increase in the end of day period is due to stock price demand increase in the end of the day, and

2. The buyers initiate much of the trading overreaction in the end of day period.
The studies developed to investigate intraday of the week were conducted by Oldfield and Rogalski (1980), French(1980), Lakonishokand Levi (1982), Gibbon and Hess (1981), Keim and Stambaugh (1983), and Smirlock and Starks (1983). Oldfield and Rogalski (1980) and French (1980) find that stock return on Monday is three periods bigger than the other days. Lakonishok and Levi (1982), Gibbon and Hess (1981) conducted a study and conclude that there is a delay in trading, placement of stockand cashcheck liquidation.

Other studies developed using the same formula for intra hour's day of the week were conducted by Amihud and Mendelson (1987), Stoll and Welley (1990), and Huang et al. (2000). Amihud and Mendelson (1987) state that return variance for open-to-open period is bigger than the close-to-close one. Stoll and Welley (1990) conclude the same thing as Amihud and Mendelson (1987), but they also find that the result of their study is consistent with the trading mechanism hypothesis. Huang et al. (2000) developed a study which examined empirically that the return variance on the day of trading period is bigger than on the day of nontrading period. Therefore, this study focuses to investigates the return variability behavior in trading and nontrading periods to entice the time (trading) pattern when investors should have bought than sold the stocks or vice versa. 
Sumiyana -Behavior of Stock Price Variability over Trading and Nontrading Periods, and...

\section{The Factors which Influence Stock Price}

Stock price movement reflects two things; they are the influence of information arrival and noise (Huang et al. 2000). There are two kinds of information; they are public information and private information. Public information is information provided to all investors and affects the price of securities when the information is announced to all investors. Meanwhile, private information is information which is owned by only a few investors. Noise also affects the price of securities in the manner of the inaccurate investors' perception or belief for the real price of securities. Finally, the last factor that affect price of securities is the period when those securities are sold in the stock exchange.

Selection of trading period effects the security price information providing process. Generally, trading which take place during trading period and possess information contains private information, so the private information tends to directly influence return during trading. Consequently, volatility in trading period is higher than nontrading period (Guner and Onder 2002). Meanwhile, public information is not limited only during trading but also in nontrading period, so it tends to influence return in both the trading and nontrading periods. Therefore, return volatility in nontrading period is higher than in trading period because the length of period is relatively longer (Huang et al. 2000).
This study investigates stock price behavior in trading and nontrading periods in Indonesia Stock Exchange. The research methodology of this study is by investigating the stock return variance during trading and nontrading periods, developing and investigating relevant hypotheses to explain the stock price behavior. The study on stock price behavior during trading and nontrading periods shows that there is an information process in the financial market. Relative impacts on public information, private information, and noise are reflected in trading and nontrading periods. Huang et al. (2000) suggests that return variance in the trading period and return variance in the nontrading period are sensitive to market condition which includes the size, trading volume, bid-ask spread, and up-down market. Therefore, this study designs to categorize portfolio in order to investigate stock return instability in trading and nontrading periods in different market condition.

\section{Trading and Nontrading Periods in Indonesia Stock Exchange}

Trading period in Indonesia Stock Exchange consists of two sessions; they are the morning session (the first session) and the afternoon session (the second session); and is held from Monday until Friday. The first session in trading activity on Monday till Thursday is from 09.30 a.m. until 12.00 p.m. and the second session is from 1.30 p.m. until 4 p.m., except for Friday, it starts from 09.30 a.m. until 11.30 a.m. and the second session starts from 2 
Gadjah Mada International Journal of Business, September - December 2007, Vol. 9, No. 3

p.m. until 4 p.m. Between the sessions, there is lunch break, so the nontrading period variance covers the evening return variance $\left(\mathrm{R}_{1}\right)$ and the lunch break return variance $\left(R_{3}\right)$, while the trading period variance covers the first session return variance $\left(R_{2}\right)$ and the second session return variance $\left(\mathrm{R}_{4}\right)$.

The four return variables used to analyze return volatility in the 24 hours are opening and closing price in the first trading session $\left(\mathrm{O}_{1}\right.$ and $\left.\mathrm{C}_{1}\right)$ and opening and closing price in the second session $\left(\mathrm{O}_{2}\right.$ and $\left.\mathrm{C}_{2}\right)$. Variance ratio is used to analyze information arriving uniformity (Guner and Onder 2002). Information could affect price and volatility only because there is information at the same period. The daily return volatility which is calculated from the opening and closing price for each session should have the same amount. In addition, open-to-open variance and close-to-close variance are employed to analyze the influences of trading mechanism (Amihud and Mendelson 1987). The trading mechanism difference in the opening and closing of trading in Tokyo Stock Exchange(TSE) causes different volatility between open-to-open return and close-to-close return. Indonesia Stock Exchange is different from that of TSE, because at Indonesia Stock Exchange there is no difference in the opening and closing trading mechanism, so the study assumes that there is no significant difference between open-to-open variance and close-to-close variance.

\section{Research Purposes}

Current stock price behavior pattern in NYSE (New York Stock Exchange), TSE (Tokyo StockExchange), SSE (Singapore Stock Exchange), etc. are used as a tool to prove whether stock price variability behavior, stock return volatility, occurs in Indonesia Stock Exchange or not. Therefore, the purposes of this research are to:

1. Investigate return variance behavior in trading and nontrading periods,

2. Investigate the similarities and differences of daily return volatility behavior,

3. Investigate the price behavior sensitivity to market condition (controlled based on size, trading volume, bidask spread and up-down market).

\section{Research Benefits}

This research is beneficial for investors or future investors who are interested in gaining profits/gains in the capital market (FASB, SFAC No. 1, 1993). To be more specific, for investors and potential investors, this research suggests a correct timing guidance that could enhance the trading productivity in the capital market. In addition, the investors in the capital market could use the result of this study to achieve more trading gains.

This study discusses problems according to the following order. Section 1 discusses the introduction. Section 2 discusses previous studies and 
Sumiyana -Behavior of Stock Price Variability over Trading and Nontrading Periods, and...

hypotheses development. Hypotheses are investigated by using Modified Levene's F-test. Section 3 discusses the research method used to test hypotheses and section 4 discusses the research findings. Finally, section 5 discusses the conclusion obtained from the result of analyses and research findings.

\section{Previous Researches and Hypotheses Development}

\section{Public and Private Information Arrivals}

Stock price volatility begins from the investors' re-evaluation activity (Francis 1986). Reevaluating process is done by estimating the income gaining expectation and the risks to determine the stock intrinsic value by using the last data. Then, investors have to compare the result with the occurrence of price fluctuation to investigate the price normality. From this normality assessment, investors can decide to buy or to sell the stock. In this condition, there are two parties who have contradictory purposes; they are the stock-buyers who want the price to increase after the buying process and the stock-sellers who want the price to decrease. These contradictory purposes can cause the stock price volatility.

Every period the price is established, at the same period there is a balance in stock supply and demand. Stock price volatility level is equal to stock intrinsic value fluctuation, and the information arrival to investors re- ally influences the stock price re-evaluation (Francis 1986). Therefore, stock price volatility process cannot be separated from the new information arrival to the investors.

Fama (1970) concludes that stock price reflects all provided information, which covers the previous price, public and private information. Private information rarely occurs (Fama 1991), and only influences the price by the trading investors who have information and usually the trading is based on the information one day later. Public information is the information recognized at the same period when it influences price, before anyone can use it to dotrading(Frenchand Roll 1986; Berry and Howe 1994).

The signals of public information are provided by all trading, but they are assessed differently by different investors (Odean 1998). Investors, who have information or no information, do trading only if they get new information, like the potential gains or any other variables, such as wealth, preference, and investment opportunities. Investors' reaction to this information occurs when the information causes a price change which reflects investors' risk and gain expectation (Berry and Howe 1994).

Nofsinger (2001) recommends the changing of trading behavior on investors. He conducted a research on institutional investors' and individual investors' trading behavior after firm specific information was released by Wall Street Journal and macroeconomic announcement. Investors tend 
to observe the information released, especially information on earnings and dividend for the specific firm. Institutional and individual investors buy after good economic news and sell after bad economic news. It shows that public information released by Wall Street Journal and macroeconomic announcement really influence stock price volatility.

Balduzzi et al. (2001) suggest that most public information tends to influence stock price very quickly (in one hour or less). Frino and Hill (2001) support this concept that the public information announcement influences much stock price behavior in Sydney Future Exchange(SFE). The price volatility analysis, trading volume and bidask spread indicate that adjustment to new information occurs very quickly. Investors can detect the influence of the new announcement in only 240 minutes. Bid-ask spread influence analysis can be seen in 20 minutes before public information is issued and 30 minutes after the public information is issued. This increase in bid-ask spread is much related with price volatility, which implicates the market response to the public information.

Public information announcement causes the massive increase in volume and price change which result in a high abnormal return (Pritamani and Singal 2001). If the information is related to earning or suitable with the analyst's recommendation, the 20 days of abnormal return is bigger for about 3,00 percent to 4,00 percent for positive events and $-2,25$ percent for negative events. Not only public information, but the private information also influences price volatility. Grundy and Kim (2002) argue that information heterogeneity level influences the increase in price variability about 20 percent- 46 percent in comparison with homogeneous full information economy. This price variability means that the signals of private information contribute positively to price variability compared to the public information. Suhaibani and Kryzanowski(2000) by using data from Saudi Stock Market (SSM) conducted a research on new information content demand. This new bigger and more aggressive demands are caused by more information arrivals. The information supply with the low relative measurement implies that private information is a dominant factor in stock trading.

\section{Trading and Nontrading Periods}

Investors' reaction to new information is reflected in stock price change that represented risk and return earning expectation (Bery and Howe 1994). Investors respond to the public information released longer in overnight session than in trading period. Therefore, this study could make a hypothesis, that return volatility is higher in nontrading period than in trading period. Nevertheless, the results of the studies done by Amihud and Mendelson (1991) and Huang et al. (2000) suggest that return volatility is higher in trading period because of private information. Investors have private information released during the trading period, and it hypothesized that 
Sumiyana -Behavior of Stock Price Variability over Trading and Nontrading Periods, and...

return in the trading period is higher than return in nontrading period.

Trading period in Indonesia Stock Exchange consists of two sessions, the first session (in the morning) and the second session (in the afternoon). Consequently, the study assumes that return variance in the first and second session (trading period) is bigger than return variance in overnight session. In the nontrading periods, lunch break and night break sessions, return variances occurred because of trading mechanism in Indonesia Stock Exchange. Without trading, stock prices can move up-or down-ward until stated as opening price in the next trading session. It supports the study conducted by Ko et al.'s (1995) which investigated the stock price volatility on intraday behavior in Korea Stock Exchange (KSE). Information causes stock price volatility to be bigger in the trading period (the first and second session) than in overnight session. Therefore, this study hypothesizes:

H.1a: Trading period return variance in the first session $\left(R_{2}\right)$ is higher than nontrading period return variance in overnight session $\left(R_{\nu}\right)$.

H.1b: Trading period return variance in the second session $\left(R_{4}\right)$ is higher than nontrading period return variance in overnight session $\left(R_{\nu}\right)$.

Ito et al. (1998) investigate private information released during lunch break in Tokyo trading that causes the increase in price volatility. Guner and Onder (2001) support it by arguing that in Turkey, volatility during lunch break is high because of private information. If compared to the first session and the second session in trading period, volatility during the lunch break is lower because of the relatively short lunch break and lower information intensity than in the trading period (Guner and Onder 2001). Based on the return variance between the trading session and lunch break, this study hypothesizes:

H.1c: Return variance in the first session $\left(R_{2}\right)$ is higher than return variance during the lunch break $\operatorname{session}\left(R_{3}\right)$.

H.1d: Return variance in the second session $\left(R_{4}\right)$ is higher than return variance during the lunch break session $\left(R_{3}\right)$.

Guner and Onder (2002) conclude that return variance in the first session in Istanbul Stock Exchange (ISE) is higher than return variance in the second session. Comparative ratio between return variance in the morning session and the return variance in the afternoon session is 130 percent (the morning session is bigger), but it is statistically insignificant. It indicates that return in the morning session is more volatile than in the afternoon session because of abundant information and noise circulation in the morning session. Based on the existence of return variance in the first and second session, this study hypothesizes:

H.2: Return variance in the first session $\left(R_{2}\right)$ is higher than return variance in the second session ( $\left.R_{4}\right)$. 
Gadjah Mada International Journal of Business, September - December 2007, Vol. 9, No. 3

Return volatility during the lunch break is the same as the return volatility at night. This is caused by investors that are not active in getting information or the market does not respond to the public information well. On one hand, there is an argument that during lunch break, investors keep getting information. It means that during lunch break private information circulates (Ito et al. 1998). Guner and Onder (2002) support it in their study. They find out that stock price volatility during the lunch break is higher than in overnight session. This result indicates that information keep coming during the lunch break by delayed trading because of the lunch break.

However, Amihud and Mendelson (1991) do not agree with the study. They argue that information arriving level during the lunch break is low, because the trading are taking a rest due to lunch and the trading intensity decreases, so informed trading are less active in trading. In addition, the public information released has longer duration in overnight than in the lunch break session. Therefore, return volatility is higher in overnight session $\left(R_{1}\right)$ than in lunch break session $\left(R_{3}\right)$. Based on the return variance in the overnight nontrading session and in the afternoon nontrading session, this study hypothesizes:

H.3: Return variance in overnight session $\left(R_{p}\right)$ is higher than return variance in lunch break $\operatorname{session}\left(R_{3}\right)$.

\section{Daily Return}

In addition to observing the trading and nontrading variance, this study also investigates the daily return volatility. The four return variables used to analyze return volatility in 24 hours are opening and closing price in the first trading session $\left(\mathrm{O}_{1}\right.$ and $\left.\mathrm{C}_{1}\right)$ and in the second trading session $\left(\mathrm{O}_{2}\right.$ and $\left.\mathrm{C}_{2}\right)$. Guner and Onder (2002) investigate the variance return ratio to analyze information arriving uniformity in one day.

Amihud and Mendelson (1987) and Stoll and Whaley (1990) find a phenomenon that in open-to-open period, the return variance is higher than close-to-close period. Amihud and Mendelson (1987) claim that price pattern is caused by the different trading mechanism adopted by the stock exchanges to determine the price. Amihud and Mendelson (1987) and Stoll and Whaley (1990) investigated trading mechanismhypothesis by comparing open-to-open return variance and close-to-close return variance for stocks listed in NYSE. NYSE adopts two trading mechanisms. Opening price is determined by call market mechanism, while the closing price is determined by continuous method. The result is that return variance during the open-to-open period is higher than return variance in close-to-close period. The results conclusion is consistent with the trading mechanism hypothesis. 
Sumiyana -Behavior of Stock Price Variability over Trading and Nontrading Periods, and...

Figure 1. Comparison of Trading Method Mechanism

\begin{tabular}{|c|c|c|c|c|c|c|c|c|}
\hline \multirow[b]{2}{*}{ Indonesia } & \multicolumn{3}{|c|}{ First Session } & & \multicolumn{4}{|c|}{ Second Session } \\
\hline & | & $\leftarrow \mathrm{CA}$ & $\rightarrow$ & & | & $\leftarrow$ & $\mathrm{CA} \rightarrow$ & \\
\hline Hong Kong & $\mid$ & $\leftarrow \mathrm{CA}$ & $\rightarrow$ & & | & $\leftarrow$ & $\mathrm{CA} \rightarrow$ & \\
\hline Singapore & | & $\leftarrow \mathrm{CA}$ & $\rightarrow$ & 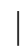 & | & $\leftarrow$ & $\mathrm{CA} \rightarrow$ & \\
\hline Turkey & | & $\leftarrow \mathrm{CA}$ & $\rightarrow$ & & | & $\leftarrow$ & $\mathrm{CA} \rightarrow$ & r \\
\hline Korea & $\mathrm{CM}$ & $\leftarrow \mathrm{CA}$ & $\rightarrow$ & & $\mathrm{CM}$ & $\leftarrow$ & $\mathrm{CA} \rightarrow$ & $\mathrm{CN}$ \\
\hline Malaysia & | & $\leftarrow \mathrm{CM}$ & $\rightarrow$ & & | & $\leftarrow$ & $\mathrm{CM} \rightarrow$ & | \\
\hline Taiwan & $\mid$ & $\leftarrow \mathrm{CM}$ & $\rightarrow$ & & & & & \\
\hline New York & $\mathrm{CM}$ & $\leftarrow \mathrm{CA}$ & $\rightarrow$ & & & & & \\
\hline Thailand & $\mathrm{CM}$ & $\leftarrow \mathrm{CA}$ & $\rightarrow$ & & $\mathrm{CM}$ & $\leftarrow$ & $\mathrm{CA} \rightarrow$ & \\
\hline Tokyo & $\mathrm{CM}$ & $\leftarrow \mathrm{CA}$ & $\rightarrow$ & & $\mathrm{CM}$ & $\leftarrow$ & $\mathrm{CA} \rightarrow$ & | \\
\hline
\end{tabular}

Notes: CM: Call Market Method; CA: Continuous Auction Method

Sources: Chang et al. (1999), and Guner and Onder (2002)

The mechanism is different from the trading mechanism in Indonesia Stock Exchange in which the opening and closing price is determined by the continuous method. It means that if trading mechanism is moving volatility, there is no significant difference between open-to-open and close-toclose variance. The differences between Indonesia Stock Exchange trading mechanism and other stock exchanges in other countries are shown in Figure 1.

Trading mechanism hypothesis is not the only factor that explains the high return volatility in the opening price of NYSE. Opening price that is more volatile than the closing price may also be caused by monopoly power of specialists and there is no trading in the whole night (Lam and Tong 1999). It is supported by a research conducted by Guner and Onder (2002) which states that open-to-open return variance in ISE (Istanbul Stock Exchange) is higher than the close-to-close return variance in the first and second session. Because of there is no different trading procedure in the opening and after break session in ISE, the return variance differ because there is no trading during the previous nontrading periods or the existence of trading halt (Amihud and Mendelson 1991). Therefore, this study frames the hypotheses below.

H.4a: open-to-open return variance in the first session $\left(O_{l}\right)$ is higher than close-to-close return variance in the first session $\left(C_{1}\right)$.

$H .4 b$ : open-to-open return variance in the first session $\left(O_{P}\right)$ is higher than close-to-close return variance in the second session $\left(C_{2}\right)$.

H.4c: open-to-open return variance in the second session $\left(\mathrm{O}_{2}\right)$ is 
Gadjah Mada International Journal of Business, September - December 2007, Vol. 9, No. 3

higher than close-to-close return variance in the first ses$\operatorname{sion}\left(C_{p}\right)$.

$\mathrm{H} .4 \mathrm{~d}$ : open-to-open return variance in the second session $\left(\mathrm{O}_{2}\right)$ is higher than close-to-close return variance in the second ses$\operatorname{sion}\left(C_{2}\right)$.

The average bid-ask spread for each hour of trading day shows that the spread is relatively high in the third hour, and then decreases until the $293^{\text {rd }}$ hour and increases until the closing trading and the spreads trading day plot can be seen as an upside down of "J" (Mcnish and Wood 1992). This analysis shows that bid-ask spread is higher in the opening of trading and decreases in the next period. It agrees with the research done by Guner and Onder (2002) which states that opening price volatility is higher than the price volatility in the afternoon. This volatility is caused by the long duration of the overnight session. There are 18 hours of nontrading day and only two hours of nontrading period in ISE. The length of nontrading period before opening influences the opening volatility. Based on the length difference of the nontrading period, this study hypothesizes:

H.5: open-to-open return variance in the first session $\left(O_{l}\right)$ is higher than open-to-open return variance in the second session $\left(\mathrm{O}_{2}\right)$.

Guner and Onder (2002) concludes that close-to-close return variance in the first session is higher than close-to-close return variance in the second session. This is caused by the level of uncertainty faced by investors in the closing of each trading session. The high level of uncertainty in the first session causes daily return volatility in the first session to be higher than the return volatility in the second session. Based on the difference of uncertainty level faced by the investors, this study hypothesizes:

H.6: close-to-close return variance in the first session $\left(C_{p}\right)$ is higher than close-to-close return variance in the second session $\left(C_{2}\right)$.

\section{Size and Return Volatility}

Fama and French (1992) suggests that size influences return more consistently and significantly than beta. The relationship between size and return is a reverse relation. Stocks of small-sized firms have higher return than big-sized firms. Investors choose to buy small firm stocks if investors consider the size factor (Sharpe et al. 1995). Gomez et al. (1998) support it by stating that size can explain risks and reflect information on risks. By using data from TSE, they concluded that firms could have equal cash flows and equal risks with the differences of market value and expected return.

Shares of small-sized firms are not traded as fast and easily as shares of big-sized-firms. Small-sized firms are vulnerable to economic condition change and tend to be not as profitable as big firms. Therefore, the shares of small-sized firms have bigger risks than that in the big ones. With the bigger risks, firms with smaller size are required to give bigger return. Chan 
Sumiyana -Behavior of Stock Price Variability over Trading and Nontrading Periods, and...

and Nai (1991) suggest that firms with smaller size are more risky because they have lower production efficiency and high leverage with low level of profitability. Consequently, the return volatility of small-sized firms tends to be higher than the big ones. Size also contains information about the stock trading speed level, production efficiency, survival, and potency of excess return in which all of them affect the risk level. Therefore, size can explain stock return variance. In addition, stocks of small-sized firms have higher price volatility than stocks in big-size firms. It can be summarized in the following hypothesis:

H.7: return variance for smaller size firms is higher than return variance for bigger size firms.

\section{Trading Volume and Return Volatility}

Trading volume is the total trading transactions in a certain period. Traders can learn valuable information on securities by observing the past price information and volume. Trading volume provides qualified data about the quality, prediction of past price, volume and the significant relation between the lag and current individual security earning (Blume et al. 1994).

Admati and Pflederer (1988) argue that the average stock sheet trading volume forms a " $U$ " pattern. It means that trading periods with high trading volume tend to have high return variability too. While the study result shows a strong relationship between trading volume and stock price change fluctuation, there are theories that explain the relationship between trading volume and stock price volatility.

Mixture of distribution hypothesis assumes that price change per transaction is related monotonously with the transaction volume and both are related to the information flow coming in which creates a relationship between volume and price movement (mixed variable). Meanwhile, the theory of difference in opinion models states that if public information changes from beneficial to not beneficial or otherwise, investors have different faith on the stock price that creates trading transaction. The latest model, asymmetric information theory argues that investors who have information do the transactions based on the private information that they get. In addition, if investors do more transactions, the return volatility will be higher.

Stock price volatility in the trading period tends to be higher for big trading volume transactions. Private information encourages high volatility in the trading which has big volume (Easley and O'Hara 1987). Informed investors do transactions based on the private information they get, and the more transaction they do, the higher the volatility is. The high volatility is caused by the private information that arrived in the trading period. When informed investors do the trading more actively, volatility increases because 
Gadjah Mada International Journal of Business, September - December 2007, Vol. 9, No. 3

of the private information spread (Admati and Pflederer 1988). Therefore, based on the increase and decrease in return volatility, this study frames a hypothesis:

H.8: Return variance in the big-trading volume is higher than return variancein small-trading volume.

\section{Bid-Ask Spread and Return Volatility}

Stock trading runs when the balance price between supply and demand arises. In many periods, supply price and demand price are not equal so the trading does not happen. Stock trading occurs because the stock price decreases or increases as buyers increase the price and sellers make the price decreases. Stock trading frequency increases when the difference between supply price and purchase price is not too large.

Bid is the highest price the future buyers are willing to pay in a certain period for a trading unit of a certain obligation. Ask is the lowest price the future seller can get from the same obligation. Those prices create a price note and the difference between both prices is called spread. Regarding the relationship between the stock spread and return, Amihud and Mendelson (1986) suggest that the higher the spread level of an asset, the higher return required. The higher spread indicates that the stock liquidity level is lower. It means that the stock is relatively hard and rare to be traded in the stock exchange.
Liquidity is defined as the capability of stock to be easily sold and bought. It is an important factor to be considered in investment decisions. The easier a stock is sold/bought, the more liquid the stock is. Investors prefer liquid stocks to the illiquid ones. The liquid stock transaction decreases the bargaining difference among investors and increases the stock trading frequency. The more liquid a stock is, the smaller the difference is in its supply price and demand price (bid-ask spread). And otherwise, if the bid-ask spread is too big, it indicates that the stock is not liquid.

Easley and O'Hara (1987) suggest that the highly traded stock has smaller risk than the rarely traded stock as a result of information arrivals related to the trading. The more inactive a stock is; the risk is higher because of many trading that are conducted by the information arrivals. For instance, financial report, merger, acquisition, or any other information gives information contents to the capital market. Rarely traded stock in the stock exchange is riskier because of the effects of specific information which is distributed into the capital market.

Stock with big spread usually has bigger risk than actively-traded stock which has smaller spread. The risk caused by high spread usually occurs in the long-owned and rarely-traded stock. On the other hand, highly-traded stock shows that investors are interested in it, which means that the stock could be is traded quickly. The condition makes the trader does not hold the 
Sumiyana -Behavior of Stock Price Variability over Trading and Nontrading Periods, and...

stock too long, which decreases inventory cost. The faster the stock is traded, the lower its inventory cost will be (Stoll 1989).

The rarely-traded stock is susceptible to price change risk. The bigger spread acts as a compensation for the higher risk of the possibility of illiquid stock. Elton et al. (2001) investigated the difference of spread between corporate bonds and government bonds. The difference between them is influenced by the expected defaults loss, local and national tax which has to be paid by corporate bonds, while the government bonds have no tax. Moreover, both bonds which have higher risk also have higher spread. Their study supports Branch and Freed's (1977) study that investors need higher spread to handle the more risky stocks. At this point, spread is a direct measurement of liquidity cost, while liquidity is defined as an ease and speed owned by the financial instruments in which they can be liquidated immediately.

The bigger the spread of a stock is; the bigger return could be expected from it. Amihud and Mendelson (1986) state that the average risk of adjusted return portfolio increases along with the bid-ask spread. The slope of the return-spread relation moves reversely with the increase in spread. Return volatility increases as the spread of a portfolio asset increases, but it usually increases in smaller amount than that of the increase of the asset. Furthermore, return volatility level is related positively with the bid-ask spread, for the trading period or nontrading period (Huang et al. 2000). Based on the bidask spread differences, this study makes a hypothesis:

H.9: return variance in big bid-ask spread is higher than return variance in small bid-ask spread.

\section{Up-down Markets and Return Volatility}

Chang et al. (1999) and Huang et al. (2000) state that the ratio between open-to-open return varianceand closeto-close return variance is sensitive to the market condition. Huang et al. (2000) suggest that if the market returns positively, the return is more positive in the trading period. And otherwise, if the market returns negatively, the return is more negative in the trading period. Trading period return variance is more positive if the market returns positively and more negative if the market returns negatively. This study infers that open-toopen return variance is higher than close-to-close return variance in positive-returned market. In addition, return variance ratio in the trading period is bigger than in nontrading period for positive-returned market. Based on the difference of return variance for different market condition, this study hypothesizes:
H.10:return variance for positive-re- turned (up) market is higher than return variance for negative-re- turned (down) market.


Gadjah Mada International Journal of Business, September - December 2007, Vol. 9, No. 3

\section{Research Method}

\section{Research Data and Samples}

Sample is limited to the firms whose stocks are included in the actively traded stock category. It is done because Indonesia Stock Exchange is a thin market which is marked by many sleeping (non-traded) stocks (Hartono, J. 2004). Therefore, the samples are the firms listed in LQ 45 indexes for the year of 1999-2006. This research chooses LQ 45 because the firms listed here are highly-liquid, so it can reduce the amount of sleeping stocks traded in the first session or the second session of the trading day. The inactive stocks will distort the accuracy of this study.

\section{Type of Data}

Data used in this study is secondary data; they are stock price intraday data that contains opening and closing price in the first and second session of trading and financial reports such as the balance or financial position reports that document total of assets, trading volume, bid-ask spread, trading day, dividend announcement, dividend stock, stock split, share bonus, reverse split and delisting firms.

\section{Data Collecting Method}

Data collecting method is documentation. Intraday data, reverse split and financial reports are obtained from Indonesia Stock Exchange and the Research and Development in Master of Science, Faculty of Economics and
Business, Universitas Gadjah Mada. Data for the trading volume, bid-ask spread, trading day, dividend announcement, and delisting firms are taken from the Faculty of Economics and Business (FEB) Universitas Gadjah Mada database, and the stock dividend data, share bonus and stock split are taken from Indonesia Capital Market Directory (ICMD).

\section{Operational Definition}

Opening and Closing Price in Each Session. Opening and closing price are obtained from the intraday data. Opening price in the first session is the price established at the first period in the first session by looking at the transaction period. If there are two or more transactions in the beginning of the session at the same period, the smallest number of transaction is used. Closing price is the last price created in the session by looking at the transaction period. If there are two or more transactions in the end of the session at the same period, the smallest number of transaction is used. There are four price series for one day; they are opening price in the first session $\left(\mathrm{P}_{\mathrm{O} 1}\right)$, closing price in the first session $\left(\mathrm{P}_{\mathrm{C} 1}\right)$, opening price in the second session $\left(\mathrm{P}_{\mathrm{O} 2}\right)$ and closing price in the second session $\left(\mathrm{P}_{\mathrm{C} 2}\right)$.

Return. Return is determined by natural logarithm of relative price $\mathrm{R}_{t}=$ $\ln \left(\mathrm{P}_{\mathrm{t}} / \mathrm{P}_{\mathrm{t}-1}\right)$. In order to calculate trading day return, four sessions of period are needed: two trading sessions $\left(\mathrm{R}_{2}\right.$ and $\mathrm{R}_{4}$ ) and two nontrading periods con- 
Sumiyana -Behavior of Stock Price Variability over Trading and Nontrading Periods, and...

sists of overnight and lunch break $\left(\mathrm{R}_{1}\right.$ and $\left.\mathrm{R}_{3}\right)$. So the patterns are $(\mathrm{t}=$ the $\ldots$ day):

Overnight Return:

$\mathrm{R}_{1, \mathrm{t}}=\ln \left(\mathrm{P}_{\mathrm{O} 1, \mathrm{t}} / \mathrm{P}_{\mathrm{C} 2, \mathrm{t}-1}\right)$

Return for the first session:

$\mathrm{R}_{2, \mathrm{t}}=\ln \left(\mathrm{P}_{\mathrm{C} 1, \mathrm{t}} / \mathrm{P}_{\mathrm{O} 1 \mathrm{t}}\right)$

Return during lunch break session:

$\mathrm{R}_{3, \mathrm{t}}=\ln \left(\mathrm{P}_{\mathrm{O} 2, \mathrm{t}} / \mathrm{P}_{\mathrm{C} 1, \mathrm{t}}\right)$

Return for the second session:

$\mathrm{R}_{4, \mathrm{t}}=\ln \left(\mathrm{P}_{\mathrm{C} 2, \mathrm{t}} / \mathrm{P}_{\mathrm{O} 2, \mathrm{t}}\right)$
Meanwhile, to analyze the daily return volatility, I use this return pattern:

Opening price first session return:

$\mathrm{R}_{\mathrm{O} 1 \mathrm{t}}=\ln \left(\mathrm{P}_{\mathrm{O} 1, \mathrm{t}} / \mathrm{P}_{\mathrm{O} 1, \mathrm{t}-1}\right)$

Closing price first session Return:

$\mathrm{R}_{\mathrm{C} 1, \mathrm{t}}=\ln \left(\mathrm{P}_{\mathrm{C} 1, \mathrm{t}} / \mathrm{P}_{\mathrm{C} 1, \mathrm{t}-1}\right)$

Opening price second session Return :

$\mathrm{R}_{\mathrm{O} 2 \mathrm{t}}=\ln \left(\mathrm{P}_{\mathrm{O} 2, \mathrm{t}} / \mathrm{P}_{\mathrm{O} 2, \mathrm{t}-1}\right)$

Closing price second session Return: $\mathrm{R}_{\mathrm{C} 2, \mathrm{t}}=\ln \left(\mathrm{P}_{\mathrm{C} 2, \mathrm{t}} / \mathrm{P}_{\mathrm{C} 2, \mathrm{t}-1}\right)$

\section{Figure 2. Transaction Period in Indonesian Stock Exchange}
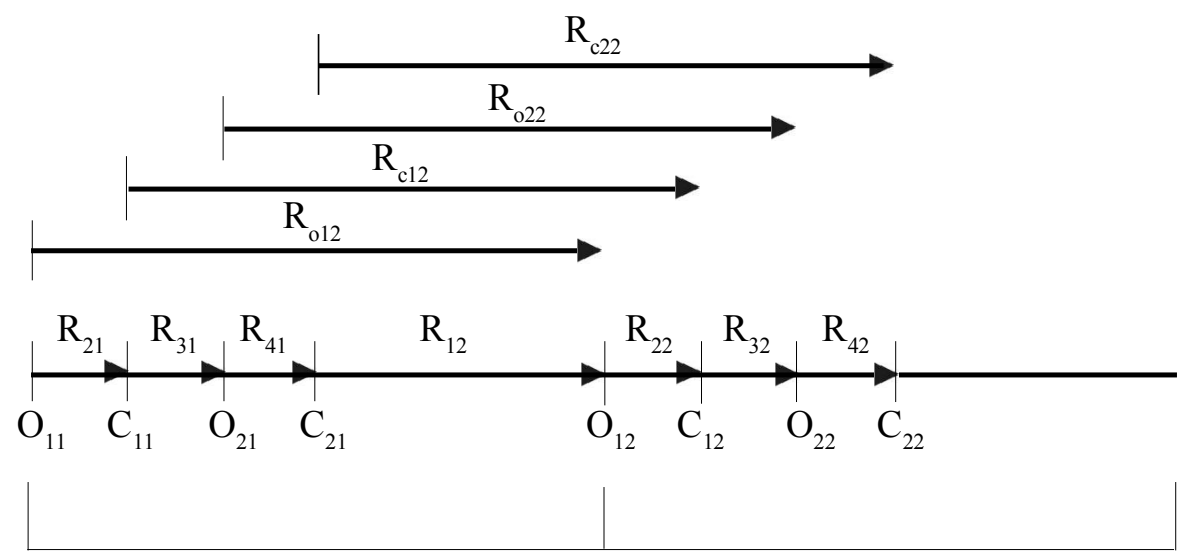

day $\mathrm{t}=1$

day $\mathrm{t}=2$

O Opening of the first session, 09.30 a.m.

$\mathrm{C}_{1}$ Closing of the first session, 12.00 p.m. for Monday-Thursday and 11.30 a.m. for Friday

$\mathrm{O}_{2}$ Second session closing, 1.30 p.m. for Monday-Thursday and 2.00 p.m. for Friday

$\mathrm{C}_{2}$ Second session closing, 4 p.m.

$\mathrm{R}_{\mathrm{ijt}} \ln \left(P_{i j t} / P_{i j, t-1)}\right)$ is return for transaction $i j(i=$ ofor opening, $c$ for closing; $j=1$ for the first session,

2 for the second session) from day ( $t-1)$ to $t$ day.

$\mathrm{R}_{\mathrm{kt}}$ return in interval $k$ on day $t$, where:

$\mathrm{K} 2$ for the first session (09.30-12.00 for Monday-Thursday, and 09.30-14.00 for Friday)

$\mathrm{K} 3$ for lunch break (12.00-12.30 for Monday-Thursday, and 13.30-14.00 for Friday)

$\mathrm{K} 4$ for the second session (12.30-16.00 for Monday-Thursday, and 14.00-16.00 for Friday)

$\mathrm{K} 1$ for night interval (from 16.00 on day ( $t-1)$ until 09.00 on day t)

Sources: Chang et al. (1999), and Guner and Onder (2002) 
Gadjah Mada International Journal of Business, September - December 2007, Vol. 9, No. 3

Trading period is not the same for each day. Figure 2 shows trading period (for the first and second session), nontrading period (lunch break and overnight), and daily return for the opening and closing price in the first session and the opening and closing price in the second trading session.

Portfolio. Market portfolio is created by using equal-weighted method daily. Meanwhile, market portfolio is done by taking the following operational variables, 1). Size is measured by total of assets, 2 ). Trading volume is the total trading transaction in one day, 3 ). Market return is calculated from the average of close-to-close return of all samples, and 4). Bid-ask spread is calculated by subtracting bid price from ask price and dividing it by the mean of ask price and bid price.

Procedural Steps for Analyzing

Data. These are the procedural steps to analyze data:

1. From intraday data, four price series can be obtained, they are opening price in the first session $\left(\mathrm{P}_{\mathrm{O} 1}\right)$, closing price in the first session $\left(\mathrm{P}_{\mathrm{Cl}}\right)$, opening price in the second session, opening price $\left(\mathrm{P}_{\mathrm{O} 2}\right)$ and closing price in the second session $\left(\mathrm{P}_{\mathrm{C} 2}\right)$.

2. Creating four series of return, they are:

a. Two trading period return for morning trading session and afternoon trading session, and

b. Two nontrading period return for lunch break session and night session.
3. Creating four daily return, they are:

a. opening price the first session $\left(\mathrm{P}_{\mathrm{O} 1}\right)$ compared to opening price the first session on the previous day $\left(\mathrm{P}_{\mathrm{O} 1(\mathrm{t}-1)}\right)$,

b. closing price the first session $\left(\mathrm{P}_{\mathrm{Cl}}\right)$ compared to the closing price in the first session on the previous day $\left(\mathrm{P}_{\mathrm{C} 1(\mathrm{t}-1)}\right)$,

c. Opening price in the second session $\left(\mathrm{P}_{\mathrm{O} 2}\right)$ compared to opening price in the second session on the previous day $\left(\mathrm{P}_{\mathrm{O} 2(\mathrm{t}-1)}\right)$, and

d. Closing price in the second session $\left(\mathrm{P}_{\mathrm{C} 2}\right)$ compared to closing price in the second session on the previous day $\left(\mathrm{P}_{\mathrm{C} 2(\mathrm{t}-1)}\right)$.

4. Getting rid of samples which have no trading session from the calculation.

5. Getting rid of days around dividend announcement from the samples to avoid too sharp price fluctuation $(\mathrm{H}-3$ and $\mathrm{H}+3)$.

6. Making an adjustment to stock dividend, stock split, share bonus and stock reserve split.

7. Creating market portfolio based on useful daily return to analyze stock price behavior during trading and nontrading periods.

8. Proving return volatility level from the variances of trading period return, nontrading period return, and open-to-open return and close-toclose return for the first and the second session, with formula

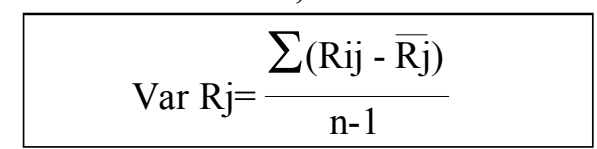


Sumiyana - Behavior of Stock Price Variability over Trading and Nontrading Periods, and...

Note:

Var $R_{j}$ : Variance return for period of $j$

$\mathrm{R}_{\mathrm{ij}} \quad$ : return for day $i$, period of $j$ intraday

$\overline{\mathrm{R}_{\mathrm{j}}} \quad$ : sample of mean return for $j$ period

n $\quad$ : number of sample

9. Conduct testing between trading period return variance and nontrading period return variance, and among daily return variance by using modified Levene method (Levene 1960, and Forsythe 1974).

$$
F=\frac{\sum_{j=1}^{J} n_{j}\left(D_{o j}-D_{o o}\right)^{2} /(j-1)}{\sum_{j=1}^{J} \sum_{i=1}^{n_{j}}\left(D_{i j}-D_{o j}\right)^{2} /(N-J)}
$$

Note:

$\mathrm{D}_{\mathrm{ij}}:\left|\mathrm{R}_{\mathrm{ij}}-\mathrm{M}_{\mathrm{oj}}\right|$

$\mathrm{R}_{\mathrm{ij}}$ : return for day $i$, period of $j$ intraday

$\mathrm{M}_{\mathrm{oj}}$ : sample of median return for $j$ period

$\mathrm{D}_{\mathrm{oj}}: \sum_{\mathrm{i}=1}^{\mathrm{n}_{\mathrm{j}}} \mathrm{D}_{\mathrm{ij}} / \mathrm{n}_{\mathrm{j}}$ is the mean of absolute deviation from median of $j$ period

$\mathrm{D}_{\mathrm{oo}}: \sum_{\mathrm{j}=1}^{\mathrm{J}} \sum_{\mathrm{i}=1}^{\mathrm{n}_{\mathrm{j}}} \mathrm{D}_{\mathrm{ij}} / \mathrm{N}$ is the last mean

$\mathrm{N}: \sum_{\mathrm{j}=1}^{\mathrm{J}} \mathrm{n}_{\mathrm{j}}$

$\mathrm{F}_{\text {tabel }}: \mathrm{F}(\mathrm{J}-1, \mathrm{~N}-\mathrm{J})$
10.Making size quintiles to analyze price behavior in the trading period and nontrading period sensitivity and variance ratio between opento-open return variance and closeto-close return variance. This size is used as a control variable.

11.Creating trading volume quintiles by categorizing firms based on the daily trading volume according to the generally running year. Moreover, this trading volume is used as a control variable.

12.Making bid-ask spread quintiles with relative spread with range sharing of:

a. $0.00 \% \leq$ relative spread $<1,00 \%$,

b. $1.00 \% \leq$ relative spread $<2,00 \%$,

c. $2.00 \% \leq$ relative spread $<3,00 \%$,

d. $3.00 \% \leq$ relative spread $<4,00 \%$, e. $4.00 \% \leq$ relative spread.

Range of this relative spread is then used as a control variable.

13.Dividing samples into two, daily return in up condition or in down condition or notably when $r_{m}>0$ and $\mathrm{r}_{\mathrm{m}} \leq 0$, which is used to determine the sensitivity level of price behavior in the trading and nontrading periods, and variance ratio between open-to-open return variance and close-to-close return variance. Up-down market conditions are also used as a control variable.

\section{Findings and Analyses}

This section discusses data analyses and research findings derived from the data analyses. The order of discus- 
Gadjah Mada International Journal of Business, September - December 2007, Vol. 9, No. 3

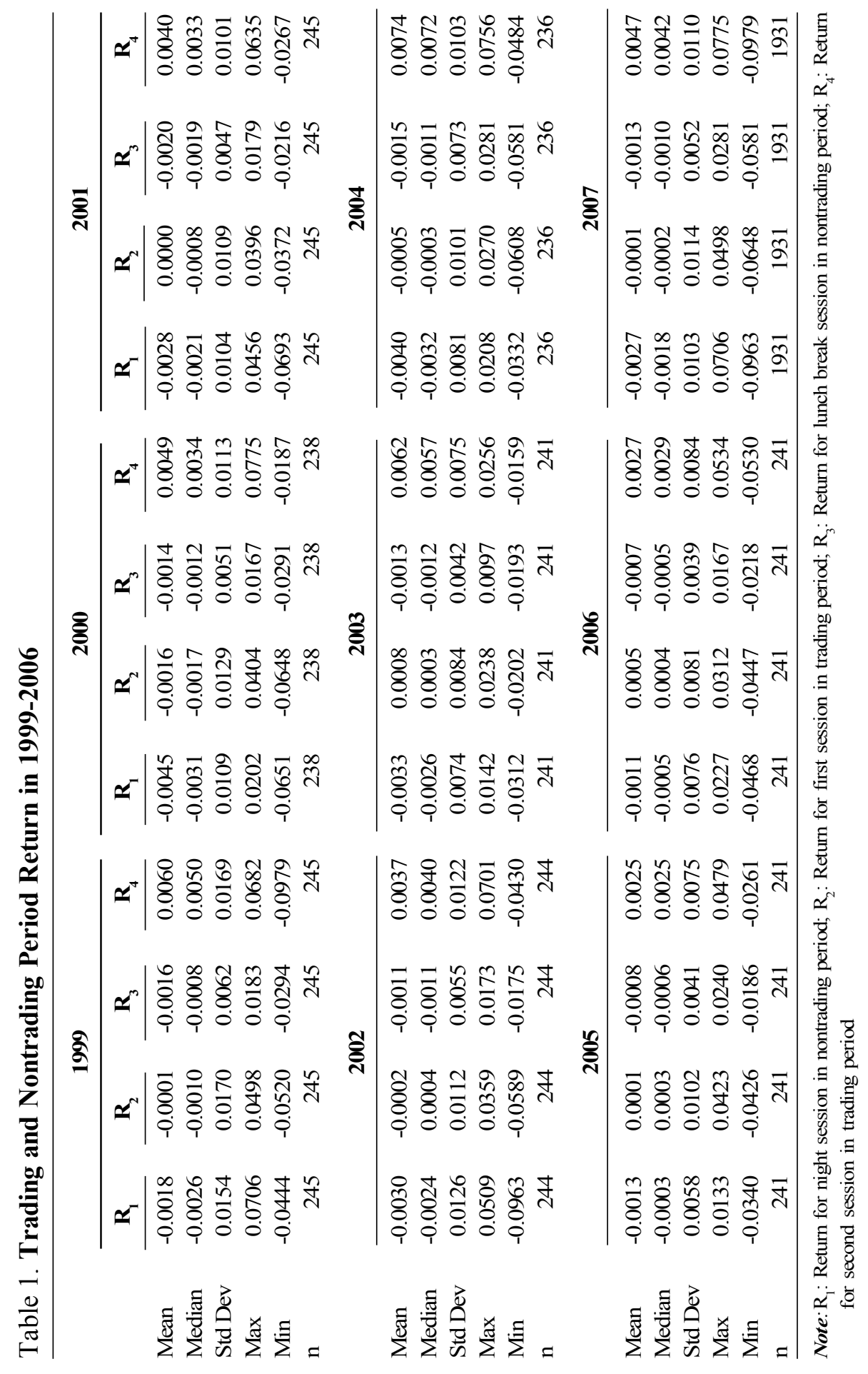


Sumiyana -Behavior of Stock Price Variability over Trading and Nontrading Periods, and...

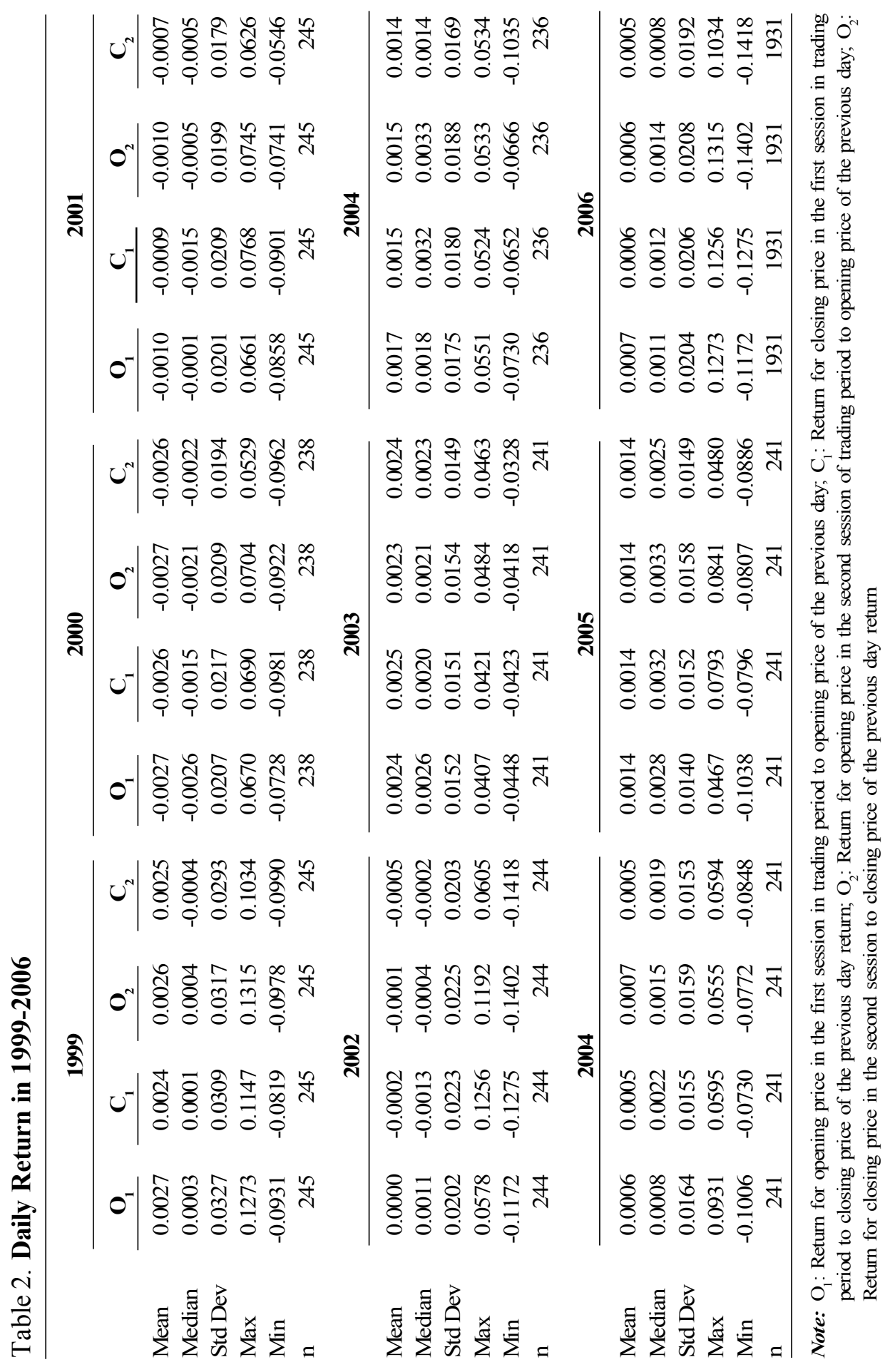


sion will begin from the descriptive statistic, stocks price variability in trading and nontrading periods, and daily return volatility. The descriptive statistic will be discussed in the following section.

\section{Descriptive Statistics}

The first descriptive statistic describes the results of return variance for all sessions in trading and nontrading periods in Table 1. From the table, it can be inferred that the first session trading period return $\left(\mathrm{R}_{2}\right)$ has a bigger return variance than the second session trading period return $\left(\mathrm{R}_{4}\right)$ and the night and lunch break session in nontrading period return $\left(\mathrm{R}_{1}\right.$ and $\left.\mathrm{R}_{3}\right)$ for each year. In general, the first session in trading period return variance $\left(\mathrm{R}_{2}\right)$ also has bigger return variance than the second session in trading period return variance $\left(R_{4}\right)$ and the night and lunch break session in nontrading period return variance $\left(\mathrm{R}_{1}\right.$ and $\left.\mathrm{R}_{3}\right)$. Furthermore, from the lowest return variance, this study notices that the lunch break session in nontrading period $\left(\mathrm{R}_{3}\right)$ has lower variance than the first and second session in trading period $\left(\mathrm{R}_{2}\right.$ and $\mathrm{R}_{4}$ ) and the night session in nontrading period $\left(\mathrm{R}_{1}\right)$.

The second descriptive statistic shows the daily return that is derived from the four prices in each trading session; they are the opening price in the first session trading period $\left(\mathrm{O}_{1}\right)$, the closing price in the first session trading period $\left(\mathrm{C}_{1}\right)$, the opening price in the second session in trading period $\left(\mathrm{O}_{1}\right)$, and the closing price in the sec- ond session in trading period $\left(\mathrm{C}_{2}\right)$ which are exhibited in Table 2. The data in this table concludes that return variance is bigger for the opening price in the first session in trading period and closing price in the second session in trading period. If both of them are compared, the return variance is the biggest in the closing price in the second session in trading period $\left(\mathrm{C}_{2}\right)$.

\section{Stock Return Variability in Trading and Nontrading Periods}

Data contained in Table 1 is sequentially analyzed to Table 3 . Table 3 shows the return variance ratio between trading and nontrading periods and vice versa. This return variance ratio is used to observe the difference in return of the fourth period. In general, stock return variability, which also means stock return volatility, shows that the session in trading period return is more unstable (volatile) than the session in nontrading period return, which is shown in $R_{2} / R_{3}, R_{4} / R_{3}$, $R_{2} / R_{l}$, and $R_{4} / R_{1}$ ratios.

The instability of the night session in nontrading period stock return when compared to the lunch break session in nontrading period $\left(\mathrm{R}_{1} / \mathrm{R}_{3}\right)$ is statistically significant. The cause of high volatility is in the lunch break session of nontrading period $\left(\mathrm{R}_{3}\right)$ which is the lowest. This study also investigated significant differences for $\mathrm{R}_{2} / \mathrm{R}_{3}$, and $R_{4} / R_{3}$. The first and second session in trading period return variance ratio $\left(\mathrm{R}_{2} / \mathrm{R}_{4}\right)$ also shows that there is a return volatility. 
Sumiyana -Behavior of Stock Price Variability over Trading and Nontrading Periods, and...

Table 3. Return Variance Ratio for Trading and Nontrading Periods

\begin{tabular}{|c|c|c|c|c|c|c|}
\hline & \multicolumn{2}{|c|}{1999} & \multicolumn{2}{|c|}{2000} & \multicolumn{2}{|c|}{2001} \\
\hline & Ratio & F-Levene & Ratio & F-Levene & Ratio & F-Levene \\
\hline $\mathrm{H}_{1}: \mathrm{R}_{2} / \mathrm{R}_{1}$ & 1.2154 & 2.3287 & $1.4150 * *$ & 4.3743 & 1.0951 & 2.1054 \\
\hline $\mathrm{H}_{1 \mathrm{~b}}: \mathrm{R}_{4} / \mathrm{R}_{1}$ & 1.2116 & 0.3511 & 1.0861 & 0.2137 & 0.9433 & 0.4024 \\
\hline $\mathrm{H}_{1 \mathrm{c}}: \mathrm{R}_{2} / \mathrm{R}_{3}$ & $7.4459 * * *$ & 118.4409 & $6.3892 * * *$ & 78.5512 & $5.3378 * * *$ & 68.8348 \\
\hline $\mathrm{H}_{1 \mathrm{~d}}: \mathrm{R}_{4} / \mathrm{R}_{3}$ & $7.4226 * * *$ & 81.9198 & $4.9043 * * *$ & 55.0418 & $4.5977 * * *$ & 58.1820 \\
\hline $\mathrm{H}_{2}: \mathrm{R}_{2} / \mathrm{R}_{4}$ & 1.0031 & 0.7086 & 1.3028 & 2.6432 & 1.1610 & 0.7807 \\
\hline \multirow[t]{2}{*}{$\mathrm{H}_{3}: \mathrm{R}_{1} / \mathrm{R}_{3}$} & $6.1262 * * *$ & 89.3926 & $4.5154 * * *$ & 49.7077 & $4.8742 * * *$ & 37.9116 \\
\hline & \multicolumn{2}{|c|}{2002} & \multicolumn{2}{|c|}{2003} & \multicolumn{2}{|c|}{2004} \\
\hline $\mathrm{H}_{1 \mathrm{a}}: \mathrm{R}_{2} / \mathrm{R}_{1}$ & 0.7901 & 0.0084 & $1.3072 *$ & 2.9850 & $1.5602 * *$ & 4.7963 \\
\hline $\mathrm{H}_{1 \mathrm{~b}}: \mathrm{R}_{4} / \mathrm{R}_{1}$ & 0.9351 & 0.0400 & 1.0421 & 0.0129 & 1.6049 & 1.7638 \\
\hline $\mathrm{H}_{1 \mathrm{c}}: \mathrm{R}_{2} / \mathrm{R}_{3}$ & $4.1395 * * *$ & 58.0815 & $4.0756 * * *$ & 76.7751 & $1.9304 * * *$ & 22.8101 \\
\hline $\mathrm{H}_{1 \mathrm{~d}}: \mathrm{R}_{4} / \mathrm{R}_{3}$ & $4.8994 * * *$ & 51.1403 & $3.2491 * * *$ & 54.8653 & $1.9857 * * *$ & 14.4374 \\
\hline $\mathrm{H}_{2}: \mathrm{R}_{2} / \mathrm{R}_{4}$ & 0.8449 & 0.1019 & 1.2544 & 2.5494 & 0.9722 & 0.4624 \\
\hline \multirow[t]{2}{*}{$\mathrm{H}_{3}: \mathrm{R}_{1} / \mathrm{R}_{3}$} & $5.2394 * * *$ & 41.0736 & $3.1178 * * *$ & 55.5505 & $1.2373 * * *$ & 8.8895 \\
\hline & \multicolumn{2}{|c|}{2005} & \multicolumn{2}{|c|}{2004} & \multicolumn{2}{|c|}{2006} \\
\hline $\mathrm{H}_{1 \mathrm{a}}: \mathrm{R}_{2} / \mathrm{R}_{1}$ & $3.0952 * * *$ & 32.4448 & 1.1272 & 2.5735 & $1.2360 * * *$ & 22.7521 \\
\hline $\mathrm{H}_{1 \mathrm{~b}}: \mathrm{R}_{4} / \mathrm{R}_{1}$ & $1.6742 * * *$ & 7.9895 & 1.2028 & 0.3066 & $1.1535 * *$ & 4.4202 \\
\hline $\mathrm{H}_{1 \mathrm{c}}: \mathrm{R}_{2} / \mathrm{R}_{3}$ & $6.3441 * * *$ & 77.4649 & $4.2659 * * *$ & 65.6402 & $4.7562 * * *$ & 509.0204 \\
\hline $\mathrm{H}_{1 \mathrm{~d}}: \mathrm{R}_{4} / \mathrm{R}_{3}$ & $3.4316 * * *$ & 43.4863 & $4.5521 * * *$ & 37.3736 & $4.4389 * * *$ & 361.9728 \\
\hline $\mathrm{H}_{2}: \mathrm{R}_{2} / \mathrm{R}_{4}$ & $1.8487 * * *$ & 10.1236 & 0.9371 & 0.9052 & $1.0715 * *$ & 6.5983 \\
\hline $\mathrm{H}_{3}: \mathrm{R}_{1} / \mathrm{R}_{3}$ & $2.0497 * * *$ & 16.0614 & $3.7844 * * *$ & 35.1921 & $3.8480 * * *$ & 298.8777 \\
\hline
\end{tabular}

This study is successful in examining the instability in the first session of trading period return and the second session of trading period return compared to those of the nontrading period. For that reason, hypotheses 1.a, 1.b, 1.c, and 1.d are supported. Inmeaning, there is a statistically significant return variance difference for the trading period compared to nontrading period. This study supports to the three studies conducted in NYSE by Amihud and Mendelson (1991), Jain and Joh (1988), Harris (1986), Wood et al. (1985). This research also supports the study that Ko et al. (1995) did in KSE, and Huang et al. (2000) did in Taiwan Stock Exchange.

This study is also successful in examining that there is instability in the first session in trading period return compared to the second session in trading period. Furthermore, there is instability in overnight session in non- 
Gadjah Mada International Journal of Business, September - December 2007, Vol. 9, No. 3

trading period compared to the lunch break session of nontrading period. For this reason, hypotheses 2 and 3 are supported. In meaning, there is a statistically significant return variance difference for the first and second session in trading period, and the overnight and lunch break session in nontrading period. The two hypotheses are supported, so this study supports the re- search done by Amihud and Mendelson (1991), Ko et al. (1995), and Guner and Onder (1991).

\section{Daily Stock Return Volatility}

The data in Table 2 is analyzed sequentially in Table 4 . Table 4 shows daily return variance ratio between opening and closing price in trading and nontrading periods. This daily re-

Table 4. Daily Return Variance Ratios

\begin{tabular}{|c|c|c|c|c|c|c|}
\hline & \multicolumn{2}{|c|}{1999} & \multicolumn{2}{|c|}{2000} & \multicolumn{2}{|c|}{2001} \\
\hline & Ratio & F-Levene & Ratio & F-Levene & Ratio & F-Levene \\
\hline $\mathrm{H}_{4}: \mathrm{O}_{1} / \mathrm{C}_{1}$ & 1.1189 & 1.0326 & 0.9155 & 0.1236 & $\overline{0.9172}$ & 0.0003 \\
\hline $\mathrm{H}_{4}^{4 \mathrm{a}}: \mathrm{O}_{1} / \mathrm{C}_{2}$ & 1.2473 & 1.9539 & 1.1381 & 2.0226 & 1.2602 & 1.8344 \\
\hline $\mathrm{H}_{4}^{4 \mathrm{~b}}: \mathrm{O}_{2} / \mathrm{C}_{1}^{2}$ & 1.0486 & 0.0287 & 0.9331 & 0.0107 & 0.8989 & 0.3313 \\
\hline $\mathrm{H}_{4}^{4 \mathrm{c}} \mathrm{O} \mathrm{O}_{2}^{2} / \mathrm{C}_{2}$ & 1.1689 & 0.0258 & $1.1599 *$ & 2.8283 & 1.2349 & 0.5100 \\
\hline $\mathrm{H}_{5}: \mathrm{O}_{1} / \mathrm{O}_{2}$ & 1.0671 & 1.3281 & 0.9812 & 0.0660 & 1.0204 & 0.3392 \\
\hline \multirow[t]{2}{*}{$\mathrm{H}_{6}^{5}: \mathrm{C}_{1} / \mathrm{C}_{2}^{2}$} & 1.1148 & 0.1210 & $1.2431 *$ & 2.9857 & 1.3739 & 1.7080 \\
\hline & \multicolumn{2}{|c|}{2002} & \multicolumn{2}{|c|}{2003} & \multicolumn{2}{|c|}{2004} \\
\hline $\mathrm{H}_{4}: \mathrm{O}_{1} / \mathrm{C}_{1}$ & 0.8225 & 0.2898 & 1.0125 & 0.0499 & 0.9440 & 0.0258 \\
\hline $\mathrm{H}_{4}^{4 \mathrm{a}}: \mathrm{O}_{1} / \mathrm{C}_{2}$ & 0.9903 & 0.1558 & 1.0482 & 0.0009 & 1.0705 & 0.6315 \\
\hline $\mathrm{H}_{4}^{4 \mathrm{~b}}: \mathrm{O}_{2} / \mathrm{C}_{1}^{2}$ & 1.0160 & 0.0273 & 1.0335 & 0.1656 & 1.0949 & 0.3859 \\
\hline $\mathrm{H}_{4 \mathrm{~d}}^{4 \mathrm{c}} \mathrm{O}_{2}^{2} / \mathrm{C}_{2}$ & 1.2233 & 1.1397 & 1.0700 & 0.0483 & 1.2417 & 2.4050 \\
\hline $\mathrm{H}_{5}: \mathrm{O}_{1} / \mathrm{O}_{2}^{2}$ & 0.8095 & 0.5128 & 0.9797 & 0.0343 & 0.8622 & 0.6323 \\
\hline \multirow[t]{2}{*}{$\mathrm{H}_{6}^{3}: \mathrm{C}_{1}^{1} / \mathrm{C}_{2}^{2}$} & 1.2040 & 0.7975 & 1.0353 & 0.0399 & 1.1340 & 0.8696 \\
\hline & \multicolumn{2}{|c|}{2005} & \multicolumn{2}{|c|}{2004} & \multicolumn{2}{|c|}{2006} \\
\hline $\mathrm{H}_{4}: \mathrm{O}_{1} / \mathrm{C}_{1}$ & 1.1136 & 0.1036 & 0.8553 & 0.7870 & 0.9798 & 0.0006 \\
\hline $\mathrm{H}_{4 \mathrm{~b}}^{4 \mathrm{a}}: \mathrm{O}_{1} / \mathrm{C}_{2}$ & 1.1427 & 0.2241 & 0.8915 & 0.5856 & $1.1312 * *$ & 3.9404 \\
\hline $\mathrm{H}_{4}^{40}: \mathrm{O}_{2} / \mathrm{C}_{1}^{2}$ & 1.0484 & 0.0668 & 1.0787 & 0.0586 & 1.0138 & 0.0104 \\
\hline $\mathrm{H}_{4 \mathrm{~d}}^{4 \mathrm{c}} \mathrm{O}_{2}^{2} / \mathrm{C}_{2}$ & 1.0757 & 0.1711 & 1.1244 & 0.1407 & $1.1705 * *$ & 4.1267 \\
\hline $\mathrm{H}_{5}: \mathrm{O}_{1} / \mathrm{O}_{2}$ & 1.0622 & 0.0048 & 0.7929 & 1.2414 & 0.9665 & 0.0061 \\
\hline $\mathrm{H}_{6}^{5}: \mathrm{C}_{1} / \mathrm{C}_{2}^{2}$ & 1.0261 & 0.0238 & 1.0423 & 0.0176 & $1.1546 *$ & 3.7499 \\
\hline
\end{tabular}

Note:

*significant at level $10,00 \%$; $* *$ significant al level 5,00\%; ***significant at level $1,00 \%$

$\mathrm{O}_{1}$ : Return for opening price in the first session in trading period to opening price of the previous day;

$\mathrm{C}_{1}$ : Return for closing price in the first session in trading period to closing price of the previous day return;

$\mathrm{O}_{2}$ : Return for opening price in the second session of trading period to opening price of the previous day;

$\mathrm{O}_{2}$ : Return for closing price in the second session to closing price of the previous day return 
Sumiyana-Behavior of Stock Price Variability over Trading and Nontrading Periods, and...

turn variance ratio is used to observe the differences of daily return between opening and closing price in periods. In general, daily return variability, which means daily stock return, investigation shows that opening price daily return in trading period is more stable (not volatile) than closing price daily return of trading period, which is exhibited in the ratio $O_{I} / C_{1}, O_{I} / C_{2}, O_{2} / C_{1}$, and $\mathrm{O}_{2} / \mathrm{C}_{2}$.

This study investigates the ratio between daily opening price and daily closing price of the session in trading period. Specifically, it compares the opening price of the first and second session in trading period return to the closing price of the first and second session in trading period return. For this reason, hypotheses 4.b and 4.d are supported. It means that instability exists in opening and closing price for each session in trading period. This study supports the research done by Amihud and Mendelson (1987) and Guner and Onder (2000). Meanwhile, hypotheses 4.a and 4.c are not sup- ported because there is no daily return volatility for the closing price in the first session in trading period.

Return volatility between the daily opening price of the first session in trading period return and the opening price of the second session in trading period return $\left(\mathrm{O}_{1} / \mathrm{O}_{2}\right)$ does not show significant variance. Therefore, hypothesis 5 is not supported. Meanwhile, daily return volatility between the daily closing price of the first session in trading period return and the daily closing price of the second session in trading period return $\left(\mathrm{C}_{1} / \mathrm{C}_{2}\right)$ is statistically significant. Therefore, hypothesis 6 is also supported, because it involves the closing price of the second session in trading period return variance or daily closing price return. The result matches with the research done by Guner and Onder (2000).

\section{Controlling Based on Size}

There is a tendency that smallsized firms have higher return than

Table 5a. Size Quintiles Return Variance in Trading and Nontrading Periods

\begin{tabular}{|c|c|c|c|c|}
\hline & $\mathbf{R}_{1}$ & $\mathbf{R}_{2}$ & $\mathbf{R}_{\mathbf{3}}$ & $\mathbf{R}_{4}$ \\
\hline Smallest & 0.0001 & 0.0002 & 0.0001 & 0.0002 \\
\hline 2 & 0.0004 & 0.0004 & 0.0002 & 0.0004 \\
\hline 3 & 0.0002 & 0.0002 & 0.0001 & 0.0002 \\
\hline 4 & 0.0004 & 0.0003 & 0.0001 & 0.0005 \\
\hline Biggest & 0.0003 & 0.0003 & 0.0002 & 0.0003 \\
\hline
\end{tabular}

Note:

$\mathrm{R}_{1}$ : Return for night session in nontrading period; $\mathrm{R}_{2}$ : Return for first session in trading period; $\mathrm{R}_{3}$ : Return for lunch break session in nontrading period; $\mathrm{R}_{4}$ : Return for second session in trading period 
Gadjah Mada International Journal of Business, September - December 2007, Vol. 9, No. 3

Table 5b. Size Quintiles Daily Return Variance

\begin{tabular}{|c|c|c|c|c|}
\hline & $O_{1}$ & $\mathrm{C}_{1}$ & $\mathrm{O}_{2}$ & $\mathrm{C}_{2}$ \\
\hline Smallest & 0.0005 & 0.0005 & 0.0005 & 0.0005 \\
\hline 2 & 0.0008 & 0.0008 & 0.0009 & 0.0008 \\
\hline 3 & 0.0005 & 0.0006 & 0.0007 & 0.0005 \\
\hline 4 & 0.0006 & 0.0006 & 0.0007 & 0.0006 \\
\hline Biggest & 0.0007 & 0.0008 & 0.0007 & 0.0006 \\
\hline
\end{tabular}

Note:

$\mathrm{O}_{1}$ : Return for opening price in the first session in trading period to opening price of the previous day; $\mathrm{C}_{1}$ : Return for closing price in the first session in trading period to closing price of the previous day return; $\mathrm{O}_{2}$ : Return for opening price in the second session of trading period to opening price of the previous day; $\mathrm{O}_{2}$ : Return for closing price in the second session to closing price of the previous day return

big-sized firms. The reason is that small-sized firms do not have quick and easy trading frequency as the big ones do. In addition, small-sized firms are more vulnerable to economic and capital market efficiency. Based on this concept, this study controls whether the stock return is stable in trading period and nontrading period or not. Table 5a shows size quintiles return variance of trading and nontrading periods, and Table $5 \mathrm{~b}$ shows size quintiles daily return variance.

The ratio of trading and nontrading periods return variance for smallsized firms and big-sized firms examined is statistically and significantly different. The return variance difference shows that hypothesis 7 is not supported, but the result contradicted to the previous empirical concepts and theories. This is shown in Table 6a. Furthermore, the ratio of daily return variance for small-sized firms and bigsized firms examined is statistically and significantly different. It is shown in table $6 \mathrm{~b}$. Therefore, this study concluded that small-sized firms and bigsized firms have different return variance, for trading and nontrading periods return or daily return. However, the statistical values are inversed. Finally, this study concluded that bigsized firms have higher return than small-sized firms. In addition, this study contradicts the result of previous empirical studies.

Table 6a is sequentially analyzed to Table 7a. This table shows the ratio of trading and nontrading periods return variance controlled by size. The previous empirical study states that small-sized firms are more unstable (volatile) than the big ones (Guner and Onder 2001). Hypotheses 1.a, 1.b, 1.c, and 1.d are supported and consistent with before controlled by size in the previous subchapter. The examination shows that small-sized firms are statistically more significant than big-sized 
Sumiyana-Behavior of Stock Price Variability over Trading and Nontrading Periods, and...

Table 6a. Compare Return Variance of the Smallest-Biggest Size Firms for Trading and Nontrading Periods

\begin{tabular}{|c|c|c|c|c|}
\hline & $\mathbf{R}_{1}$ & $\mathbf{R}_{2}$ & $\mathbf{R}_{3}$ & $\mathbf{R}_{4}$ \\
\hline Ratio & $0.4824 * * *$ & $0.6355 * * *$ & $0.3457 * * *$ & $0.6007 * * *$ \\
\hline F-Levene & 81.2121 & 17.3285 & 52.4208 & 42.0777 \\
\hline
\end{tabular}

Note:

*significant at level 10,00\%; **significant al level 5,00\%; ***significant at level 1,00\% $\mathrm{R}_{1}$ : Return for night session in nontrading period; $\mathrm{R}_{2}$ : Return for first session in trading period; $\mathrm{R}_{3}$ : Return for lunch break session in nontrading period; $\mathrm{R}_{4}$ : Return for second session in trading period

Table 6b. Compare Return Variance of the Smallest-Biggest Size Firms for Daily Return

\begin{tabular}{|c|c|c|c|c|}
\hline & $O_{1}$ & $\mathrm{C}_{1}$ & $\mathrm{O}_{2}$ & $\mathrm{C}_{2}$ \\
\hline Ratio & $0.7309 * * *$ & $0.6584 * * *$ & $0.7693 * * *$ & $0.7586 * * *$ \\
\hline F-Levene & 15.0172 & 16.3992 & 10.0402 & 17.6157 \\
\hline
\end{tabular}

Note:

*significant at level 10,00\%; **significant al level 5,00\%; ***significant at level 1,00\% $\mathrm{O}_{1}$ : Return for opening price in the first session in trading period to opening price of the previous day; $\mathrm{C}_{1}$ : Return for closing price in the first session in trading period to closing price of the previous day return; $\mathrm{O}_{2}$ : Return for opening price in the second session of trading period to opening price of the previous day; $\mathrm{O}_{2}$ : Return for closing price in the second session to closing price of the previous day return

firms. Furthermore, hypothesis 2 is not supported which stated that small-sized firms are not statistically significant than big-sized firms. Hypothesis 3 is supported, but both small-size firms and big-size firms have return variances that are statistically significant. The variance return ratio should have been higher for small-size firms than big-size firms.

Table $6 \mathrm{~b}$ is consecutively analyzed with the ratio of daily return for small-sized firms compared to the big ones in Table $7 \mathrm{~b}$. This table examines hypotheses 4.a, 4.b, 4.c, 4.d, 5 and 6 which are controlled by size quintiles. This study concluded that hypotheses 4.a, 4.b, 4.c, 4.d, and 5 are not supported. Hypothesis 6 is incidentally supported and analyzed by controlling based on size is examined consistently. It means that small-sized firms are more significantly volatile than bigsized firms. 
Gadjah Mada International Journal of Business, September - December 2007, Vol. 9, No. 3

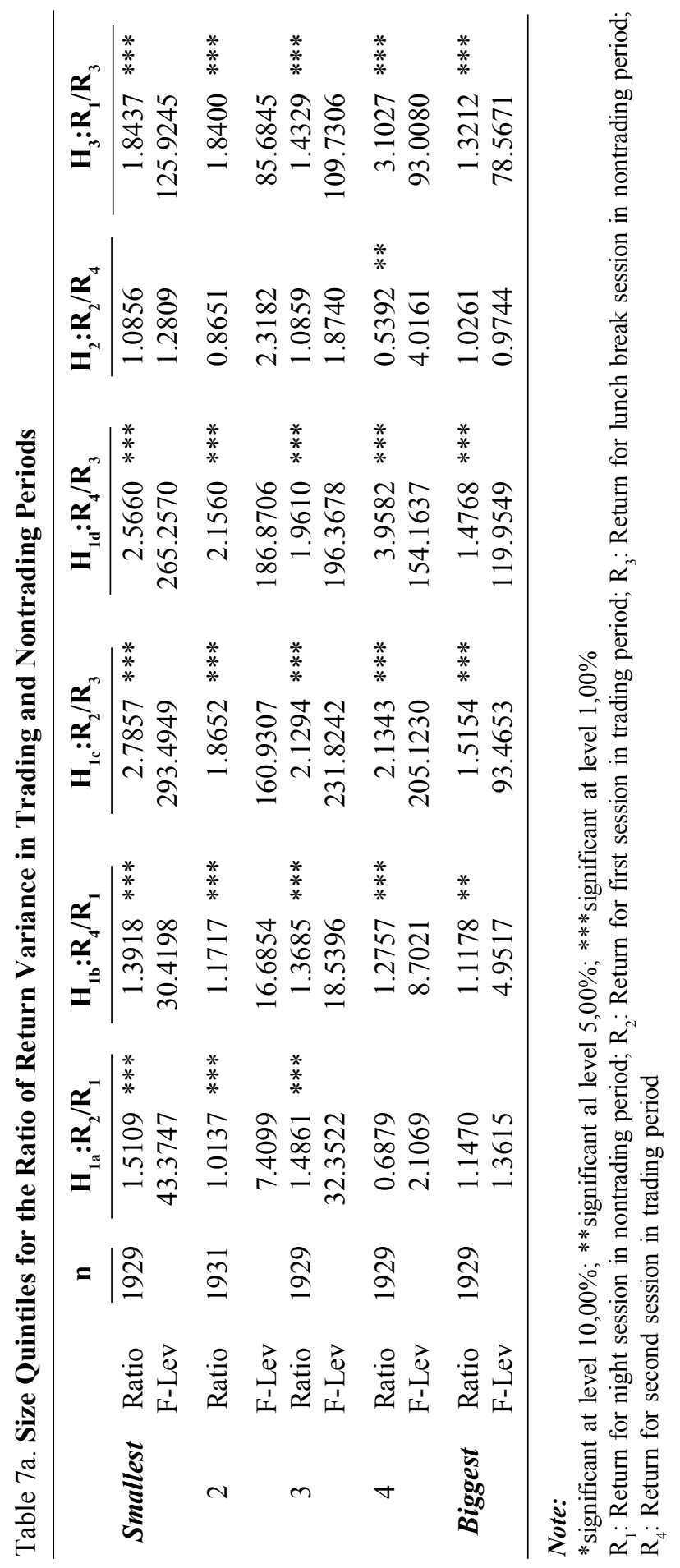


Sumiyana -Behavior of Stock Price Variability over Trading and Nontrading Periods, and...

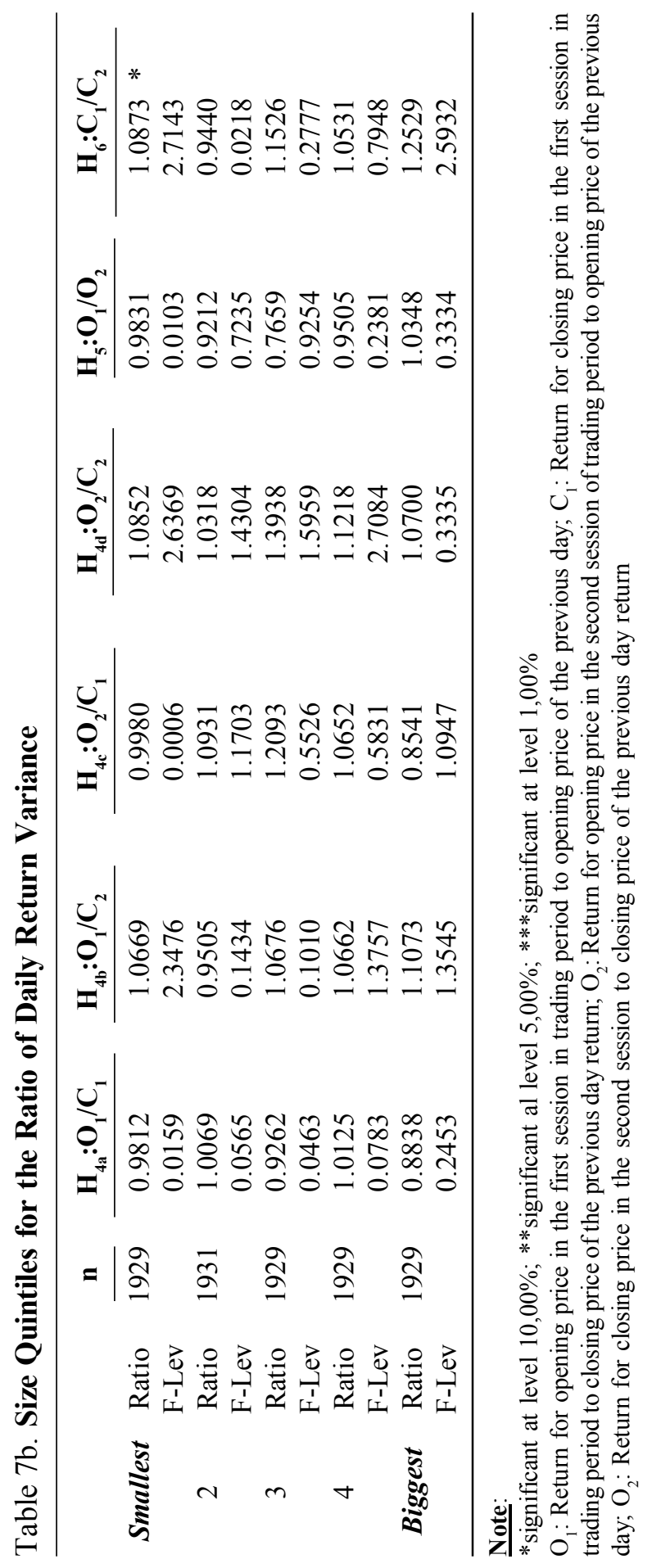


Gadjah Mada International Journal of Business, September - December 2007, Vol. 9, No. 3

Controlling Based on Trading Volume

This study use trading volume to control the price movement. The high volume indicates that stock price tends to move to higher price. And otherwise, low trading volume tends to move the price to lower price. This tendency is influenced by the stock agents' expectation to do or not to do transaction. Moreover, trading transaction volume is related to return (Easly and O'Hara 1997). Consequently, stock return in trading and nontrading periods and daily return are systematically controlled by the trading transaction volume.

Trading transaction volume is related to information arrival. Information arrival makes the demand to buy more than to sell. This condition makes the trading transaction volume increases. When the trading transaction volume is high, the return variance increases too. And otherwise, when the trading transaction weakens, the return variance decreases too (Karpoff 1987, and Admati and Pflederer 1988). Table 8 a shows return variance which is categorized by trading transaction volume level for trading and nontrading return, while Table $8 \mathrm{~b}$ shows daily return variance.

The ratio of return variance for trading and nontrading periods is categorized by trading volume quintiles exhibited in Table 9a. The study suggested that the smallest and biggest quintiles return variances are significantly different. As a result, hypothesis 8 is supported for the nontrading period and opening price for the first session in trading period. Thus, there is a significant difference in overnight and lunch break return. Meanwhile, when the daily return is analyzed, there is significant difference for opening price in the first session in trading period return shown in Table $9 \mathrm{~b}$.

Table 8a. Trading Volume Quintiles for Trading and Nontrading Return Variance

\begin{tabular}{|c|c|c|c|c|}
\hline & $\mathbf{R}_{1}$ & $\mathbf{R}_{2}$ & $\mathbf{R}_{3}$ & $\mathbf{R}_{4}$ \\
\hline Smallest & 0.00021 & 0.00024 & 0.00011 & 0.00031 \\
\hline 2 & 0.00018 & 0.00031 & 0.00015 & 0.00035 \\
\hline 3 & 0.00058 & 0.00030 & 0.00019 & 0.00068 \\
\hline 4 & 0.00050 & 0.00034 & 0.00015 & 0.00056 \\
\hline Biggest & 0.00030 & 0.00027 & 0.00028 & 0.00044 \\
\hline
\end{tabular}

Note:

$\mathrm{R}_{1}$ : Return for night session in nontrading period; $\mathrm{R}_{2}$ : Return for first session in trading period; $R_{3}$ : Return for lunch break session in nontrading period; $R_{4}$ : Return for second session in trading period 
Sumiyana-Behavior of Stock Price Variability over Trading and Nontrading Periods, and...

Table 8b. Trading Volume Quintiles for Daily Return Variance

\begin{tabular}{|c|c|c|c|c|}
\hline & $\mathrm{O}_{1}$ & $\mathrm{C}_{1}$ & $\mathbf{O}_{2}$ & $\mathrm{C}_{2}$ \\
\hline Smallest & 0.00067 & 0.00071 & 0.00088 & 0.00065 \\
\hline 2 & 0.00065 & 0.00066 & 0.00065 & 0.00064 \\
\hline 3 & 0.00068 & 0.00071 & 0.00081 & 0.00061 \\
\hline 4 & 0.00073 & 0.00071 & 0.00066 & 0.00072 \\
\hline Biggest & 0.00068 & 0.00070 & 0.00082 & 0.00064 \\
\hline
\end{tabular}

Note:

$\mathrm{O}_{1}$ : Return for opening price in the first session in trading period to opening price of the previous day; $\mathrm{C}_{1}$ : Return for closing price in the first session in trading period to closing price of the previous day return; $\mathrm{O}_{2}$ : Return for opening price in the second session of trading period to opening price of the previous day; $\mathrm{O}_{2}$ : Return for closing price in the second session to closing price of the previous day return

Table 9a. Compare Return Variance of the Smallest-Biggest Trading Volume for Trading and Nontrading Periods

\begin{tabular}{|c|c|c|c|c|}
\hline & $\mathbf{R}_{1}$ & $\mathbf{R}_{2}$ & $\mathbf{R}_{3}$ & $\mathbf{R}_{4}$ \\
\hline Ratio & $0.6773 * * *$ & 0.8863 & 0.3956 & 0.6902 \\
\hline F-Levene & 7.2672 & 1.9590 & 2.5266 & 1.8836 \\
\hline
\end{tabular}

Note:

*significant at level 10,00\%; **significant al level 5,00\%; ***significant at level 1,00\% $\mathrm{R}_{1}$ : Return for night session in nontrading period; $\mathrm{R}_{2}$ : Return for first session in trading period; $R_{3}$ : Return for lunch break session in nontrading period; $R_{4}$ : Return for second session in trading period.

Table 9b. Compare Return Variance of the Smallest-Biggest Trading Volume for Daily Return

\begin{tabular}{|c|c|c|c|c|}
\hline & $\mathrm{O}_{1}$ & $\mathrm{C}_{1}$ & $\mathrm{O}_{2}$ & $\mathrm{O}_{2}$ \\
\hline Ratio & $0.9825 *$ & 1.0136 & 1.0748 & 1.0029 \\
\hline F-Levene & 3.2868 & 1.2439 & 0.0012 & 0.9058 \\
\hline
\end{tabular}

Note:

*significant at level 10,00\%; **significant al level 5,00\%; ***significant at level 1,00\% $\mathrm{O}_{1}$ : Return for opening price in the first session in trading period to opening price of the previous day; $\mathrm{C}_{1}$ : Return for closing price in the first session in trading period to closing price of the previous day return; $\mathrm{O}_{2}$ : Return for opening price in the second session of trading period to opening price of the previous day; $\mathrm{O}_{2}$ : Return for closing price in the second session to closing price of the previous day return 
Gadjah Mada International Journal of Business, September - December 2007, Vol. 9, No. 3

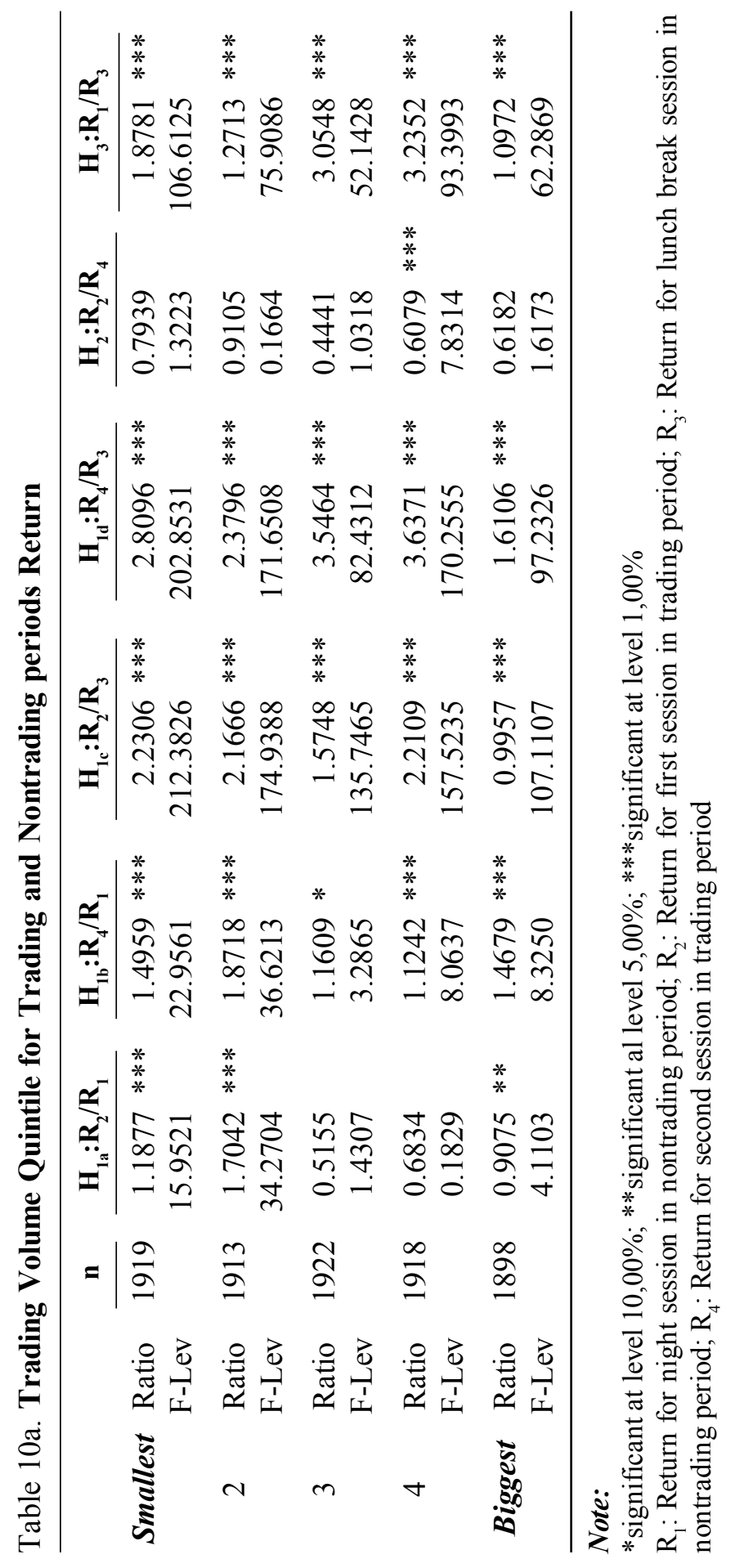


Sumiyana-Behavior of Stock Price Variability over Trading and Nontrading Periods, and...

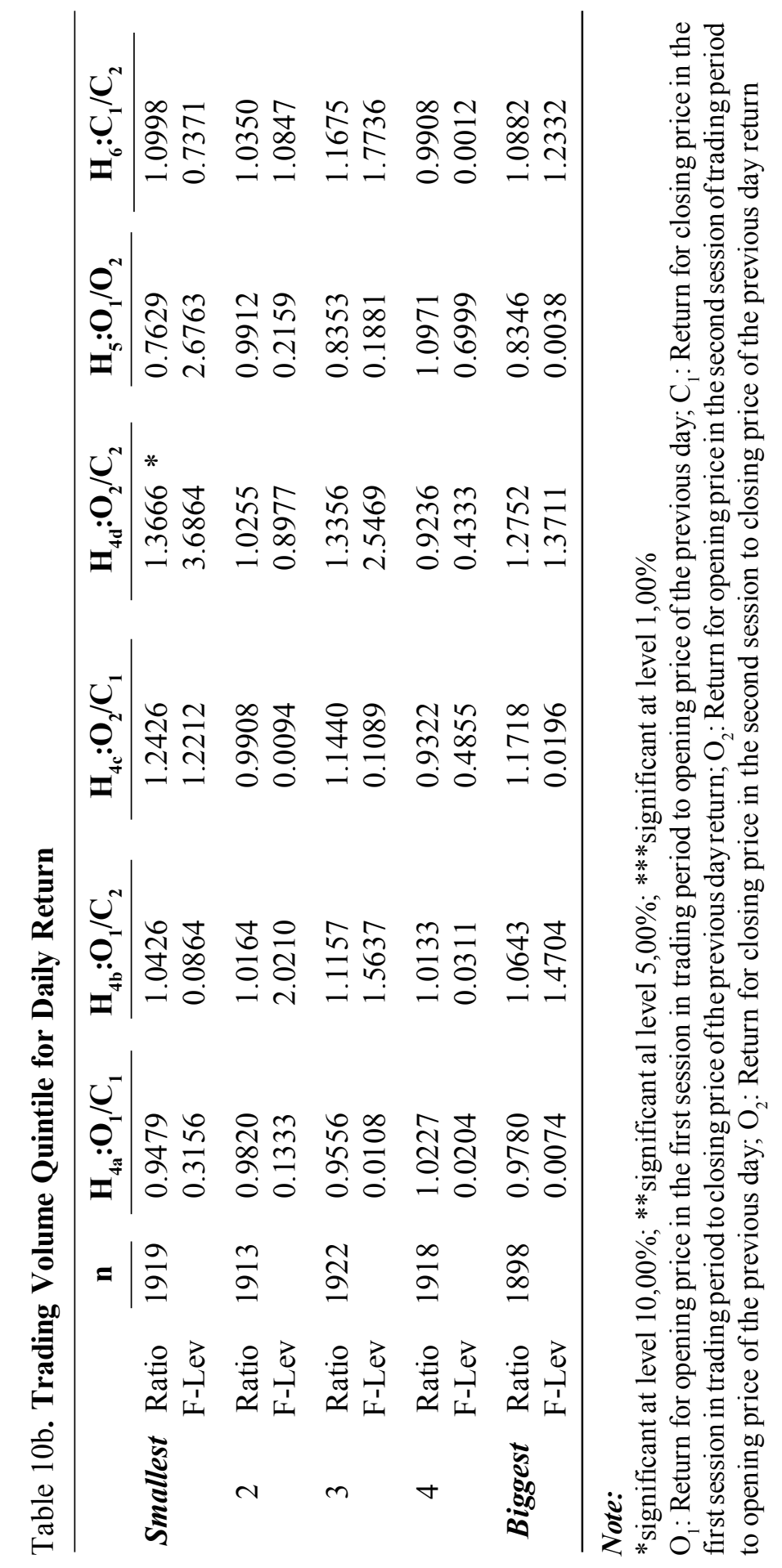


Ratio of trading and nontrading return variance controlled by the level of trading volume is exhibited in Table $10 \mathrm{a}$. From the analysis, this study suggested that the difference between trading period and the nontrading period return variance is statistically significant whether the trading volume is small or big. Therefore, hypotheses 1.a, 1.b, 1.c, and 1.d are supported. Meanwhile, the difference between the trading period and nontrading period return variance is statistically significant. Hypothesis 2 is not supported because it contains trading period return variance as a comparison denominator. Otherwise, the difference between the nontrading period and nontrading period return variance is statistically significant. Therefore, hypothesis 3 is supported. This study also contradicts previous empirical studies which show that both the smallest and the biggest trading volume is significantly different.

Daily return variance which is controlled by trading volume is reexamined to determine the hypotheses consistency to the daily return tested before. The result of the test is shown in Table 10b. The test result shows that the size of trading volume does not influence daily return variance. Therefore, all daily return variance hypotheses 4.a, 4.b, 4.c, 4.d, 5, and 6 controlled by trading volume are not supported. So, this study concluded that trading volume does not cause daily return volatility, and it shows that trading volume does not move linearly with the daily return volatility. It is appropriate that variance returns ratio for big trading volume is higher than small trading volume. Actually, both of the smallest and the biggest trading volume do not have significantly different return variance.

\section{Controlling Based on Bid-ask Spreads}

For the third reexamination, this study use bid-ask spread to control trading and nontrading return variance and daily return variance. The use of this bid-ask spread is to examine the different return variance caused by dis-

Table 11a. Bid-ask spread Quintiles for Trading and Nontrading Periods Return Variance

\begin{tabular}{|c|c|c|c|c|}
\hline & $\mathbf{R}_{1}$ & $\mathbf{R}_{2}$ & $\mathbf{R}_{\mathbf{3}}$ & $\mathbf{R}_{4}$ \\
\hline Smallest & $\overline{0.000893}$ & 0.000292 & $\overline{0.000220}$ & 0.000943 \\
\hline 2 & 0.000323 & 0.000334 & 0.000172 & 0.000434 \\
\hline 3 & 0.000316 & 0.000336 & 0.000219 & 0.000447 \\
\hline 4 & 0.000428 & 0.000496 & 0.000378 & 0.000615 \\
\hline Biggest & 0.000242 & 0.000244 & 0.000086 & 0.000201 \\
\hline
\end{tabular}

Note:

$\mathrm{R}_{1}$ : Return for night session in nontrading period; $\mathrm{R}_{2}$ : Return for first session in trading period; $\mathrm{R}_{3}$ : Return for lunch break session in nontrading period; $\mathrm{R}_{4}$ : Return for second session in trading period 
Sumiyana-Behavior of Stock Price Variability over Trading and Nontrading Periods, and...

Table 11b. Bid-ask spread Quintiles for Daily Return Variance

\begin{tabular}{|c|c|c|c|c|}
\hline & $O_{1}$ & $\mathrm{C}_{1}$ & $\mathbf{O}_{2}$ & $\mathrm{C}_{2}$ \\
\hline Smallest & 0.000711 & 0.000713 & 0.000713 & 0.000756 \\
\hline 2 & 0.000725 & 0.000765 & 0.000743 & 0.000706 \\
\hline 3 & 0.000722 & 0.000752 & 0.000874 & 0.000814 \\
\hline 4 & 0.001075 & 0.001081 & 0.001138 & 0.000918 \\
\hline Biggest & 0.000691 & 0.000701 & 0.000695 & 0.000651 \\
\hline
\end{tabular}

Note:

$\mathrm{O}_{1}$ : Return for opening price in the first session in trading period to opening price of the previous day; $\mathrm{C}_{1}$ : Return for closing price in the first session in trading period to closing price of the previous day return; $\mathrm{O}_{2}$ : Return for opening price in the second session of trading period to opening price of the previous day; $\mathrm{O}_{2}$ : Return for closing price in the second session to closing price of the previous day return

Table 12a. Compare Variance of the Smallest-Biggest Bid-Ask Spreads for Trading and Nontrading Periods

\begin{tabular}{|c|c|c|c|c|}
\hline & $\mathbf{R}_{1}$ & $\mathbf{R}_{2}$ & $\mathbf{R}_{3}$ & $\mathbf{R}_{4}$ \\
\hline Ratio & $3.6962 * * *$ & 1.1976 & $2.5680 * * *$ & $4.6930 * * *$ \\
\hline F-Levene & 36.2348 & 0.3627 & 34.0671 & 25.3184 \\
\hline
\end{tabular}

Note:

*significant at level 10,00\%; ** significant al level 5,00\%; *** significant at level 1,00\% $\mathrm{R}_{1}$ : Return for night session in nontrading period; $\mathrm{R}_{2}$ : Return for first session in trading period; $\mathrm{R}_{3}$ : Return for lunch break session in nontrading period; $\mathrm{R}_{4}$ : Return for second session in trading period

Table 12b. Compare Variance of the Smallest-Biggest Bid-Ask Spreads for Daily Return

\begin{tabular}{|c|c|c|c|c|}
\hline & $O_{1}$ & $\mathrm{C}_{1}$ & $\mathbf{O}_{2}$ & $\mathrm{C}_{2}$ \\
\hline Ratio & 1.0295 & 1.0178 & 1.0255 & 1.1610 \\
\hline F-Levene & 0.0003 & 0.7870 & 0.9756 & 0.8923 \\
\hline
\end{tabular}

Note:

*significant at level 10,00\%; ** significant al level 5,00\%; *** significant at level 1,00\% $\mathrm{O}_{1}$ : Return for opening price in the first session in trading period to opening price of the previous day; $\mathrm{C}_{1}$ : Return for closing price in the first session in trading period to closing price of the previous day return; $\mathrm{O}_{2}$ : Return for opening price in the second session of trading period to opening price of the previous day; $\mathrm{O}_{2}$ : Return for closing price in the second session to closing price of the previous day return 
Gadjah Mada International Journal of Business, September - December 2007, Vol. 9, No. 3

semination of information arrivals which finally causes the return variance (Glosten and Harris 1988; Coopeland and Galai 1983). Trading and nontrading period returns which are categorized by the bid-ask spread is shown in Table 11a. On the other hand, daily return is categorized by bid-ask spread quintiles when the bidask spread is big or small are shown in Table $11 \mathrm{~b}$.

The previous empirical studies suggest that the big bid-ask spread has higher return variance that is statistically significant in comparison with small bid-ask spread. The relation is linear; when the bid-ask spread is small, the return volatility is small too and vice versa (Branch and Fred 1977). The significant differences between trading and nontrading return variance and daily return variance are described in Table 12a and 12b. Based on those tables, hypothesis 9 is not supported. This rejection is based on the result that return variance difference is inversely proportional to the previous empirical concepts. Clearly, the statistical values are inversed. Finally, this study concludes that small bid-ask spread has higher return than big ones.

Trading and nontrading periods return variance controlled by the level of bid-ask spreads shows that there is a variance difference. This study compares trading return variance and nontrading return variance, especially for overnight session or lunch break session. When there are small bid-ask spreads and big bid-ask spreads, there are significant differences on trading and nontrading periods return variance. Therefore, hypotheses 1.a, 1.b, 1.c, and 1.d are supported when controlled by the big or small bid-ask spreads. Meanwhile, the difference between trading and nontrading periods return variance is also statistically significant. In conclusion, hypotheses 2 and 3 are supported, because the ratio of trading and nontrading periods return variance is statistically significant. The complete result is in Table 13a. This study concluded that bid-ask spread does not cause the return volatility for trading and nontrading periods. The return variance in the big bidask spread should have been higher than in the small bid-ask spread. Actually, the difference of both big and small bid-ask spreads are statistically significant. Finally, this study contradicts the previous empirical studies.

Daily return variance controlled by bid-ask spreads determines the consistency of hypotheses to the daily return which has been reexamined before. Table 13b exhibited the test results. The test result shows that the return variance of big or small bid-ask spread does not differ significantly. Hypotheses 4.a, 4.b, 4.c, 4.d, 5, and 6 controlled by bid-ask spreads are not supported by all daily return variance. Therefore, it can be concluded that bid-ask spread does not affect daily return volatility. It also concluded that the size of bid-ask spread does not move linearly with daily return volatility. To conclude, this study contradicts the previous empirical study. 
Sumiyana -Behavior of Stock Price Variability over Trading and Nontrading Periods, and...

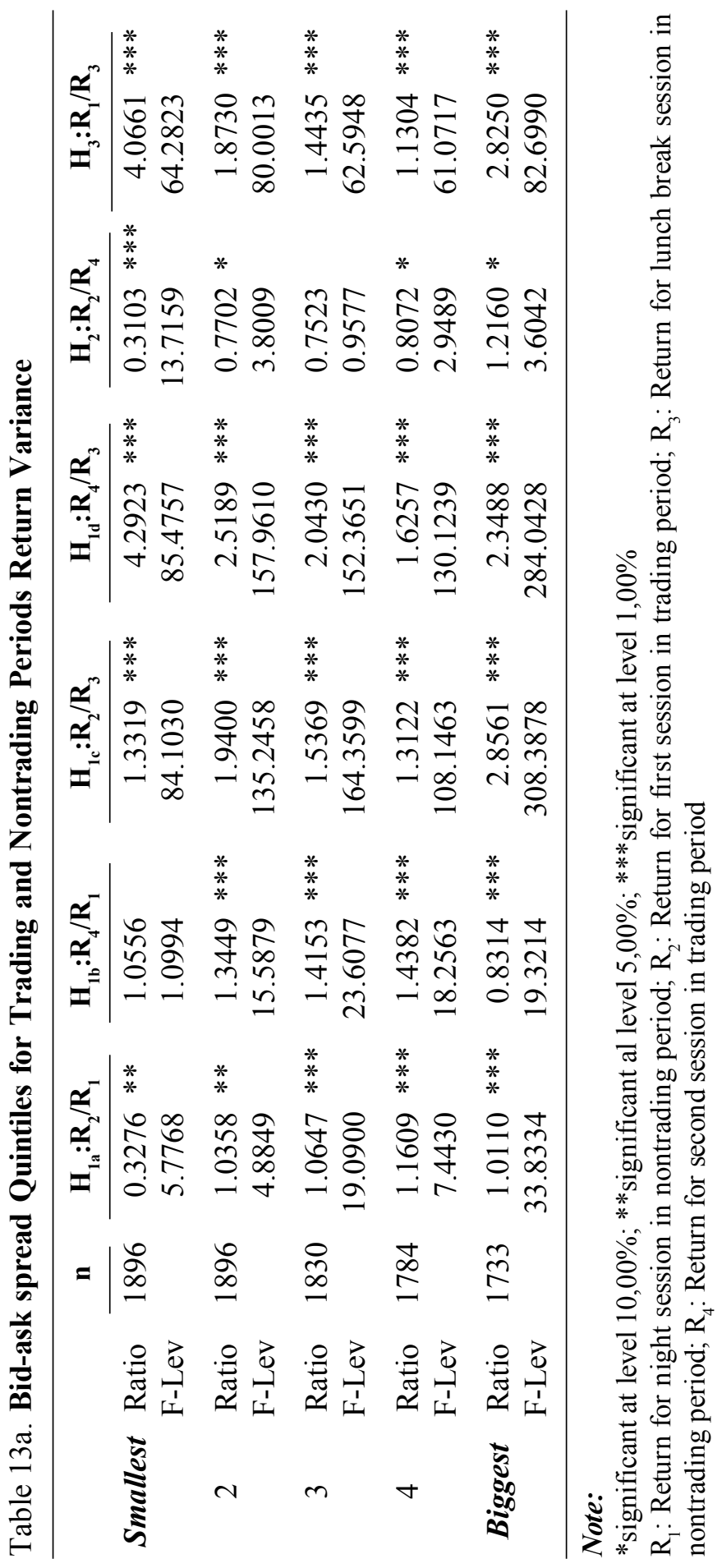


Gadjah Mada International Journal of Business, September - December 2007, Vol. 9, No. 3

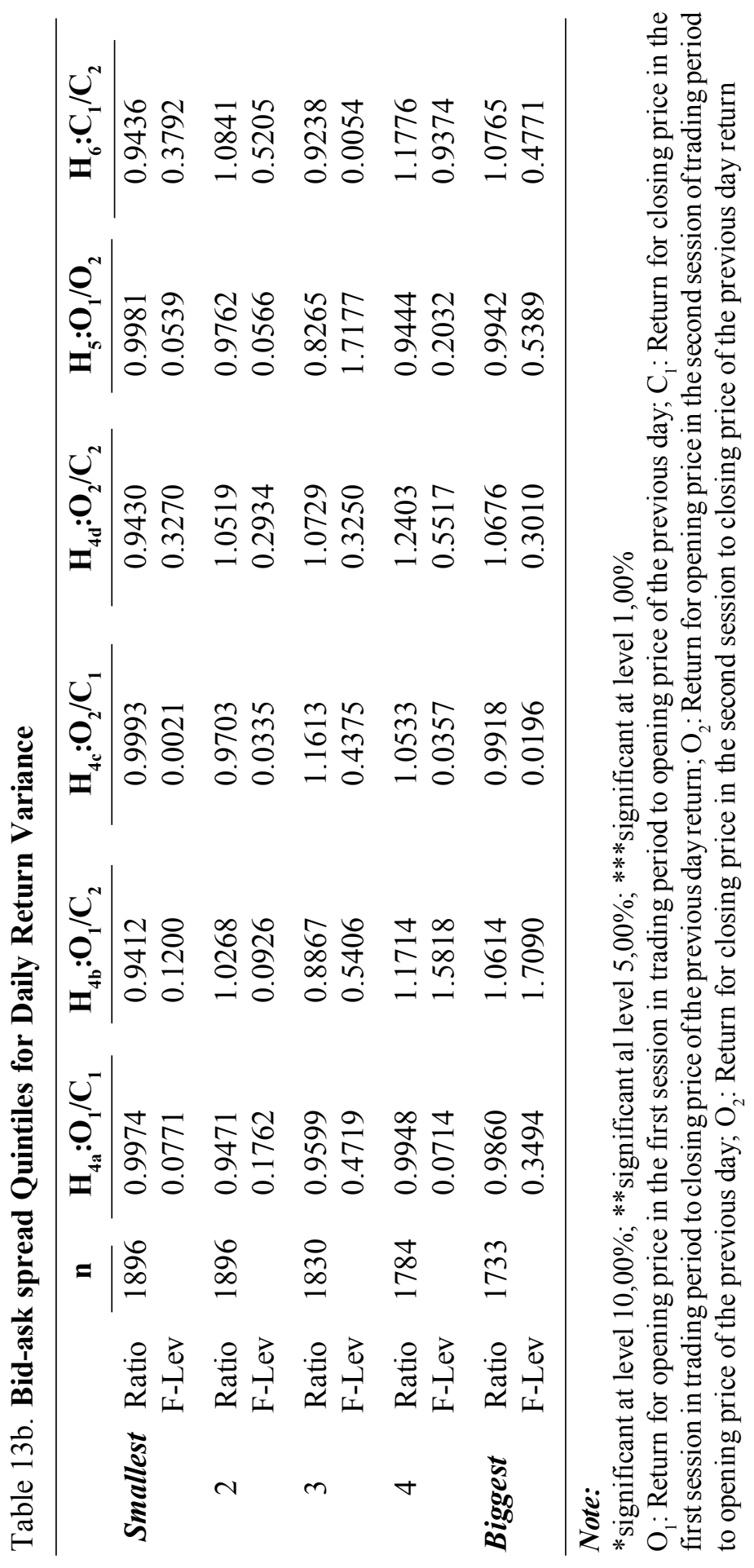


Sumiyana-Behavior of Stock Price Variability over Trading and Nontrading Periods, and...

\section{Controlling Based on Up-down Market}

There are two kinds of market condition; they are the conditions when the market increases (up-market) or when the market decreases (downmarket). Related to return, when market condition increases, the return is positive and vice versa when the market decreases, the return is negative. However, return variance is distributed unequally for every session in trading or nontrading period. The reason for this is that information arrives irregularly to the investors (Chang et al. 1993, and Huang et al. 2000). Table $14 \mathrm{a}$ shows the ratio of trading and nontrading return variance which is categorized into up-down market basis. Meanwhile, Table 14b describes the ratio of daily return variance which is classified into up-down market.

Table $14 \mathrm{a}$ and $14 \mathrm{~b}$ are sequentially analyzed for the trading and nontrading periods and daily return variance. Table 15a and Table $15 \mathrm{~b}$ exhibited test results that use up-down market to control return variance. This study suggested that the ratio of updown market return is statistically significant for the overnight and lunch break sessions in nontrading period. Meanwhile, the other ratios are not statistically significant. On the other

Table 14a. Up-Down Market for Trading and Nontrading Return Variance

\begin{tabular}{|c|c|c|c|c|}
\hline & $\mathbf{R}_{1}$ & $\mathbf{R}_{2}$ & $\mathbf{R}_{3}$ & $\mathbf{R}_{4}$ \\
\hline Up market & $\overline{0.000082}$ & $\overline{0.000098}$ & $\overline{0.000026}$ & 0.000123 \\
\hline Down market & 0.000112 & 0.000108 & 0.000029 & 0.000104 \\
\hline
\end{tabular}

Note:

$\mathrm{R}_{1}$ : Return for night session in nontrading period; $\mathrm{R}_{2}$ : Return for first session in trading period; $\mathrm{R}_{3}$ : Return for lunch break session in nontrading period; $\mathrm{R}_{4}$ : Return for second session in trading period

Table 14b. Up-Down Market for Daily Return Variance

\begin{tabular}{|c|c|c|c|c|}
\hline & $O_{1}$ & $\mathrm{C}_{1}$ & $\mathbf{O}_{2}$ & $\mathrm{C}_{2}$ \\
\hline Up market & 0.000395 & 0.000334 & 0.000330 & 0.000211 \\
\hline Down market & 0.000399 & 0.000342 & 0.000336 & 0.000246 \\
\hline
\end{tabular}

Note:

$\mathrm{O}_{1}$ : Return for opening price in the first session in trading period to opening price of the previous day; $\mathrm{C}_{1}$ : Return for closing price in the first session in trading period to closing price of the previous day return; $\mathrm{O}_{2}$ : Return for opening price in the second session of trading period to opening price of the previous day; $\mathrm{O}_{2}$ : Return for closing price in the second session to closing price of the previous day return 
side, from the examination of daily return, there is no return variance for the opening and closing price of the first and second session in trading period. Therefore, hypothesis 10 is not supported. Finally, this study concludes that the return volatility in overnight session $\left(\mathrm{R}_{1}\right)$ does not support Huang et al. (2000). Actually, all of the statistical values are inversed. Finally, this study contradicts the previous empirical studies which conclude that volatility level is increased in the downmarket condition.
The instability of trading and nontrading return variance show that updown market condition occurred when they are related to overnight and lunch break session in nontrading period. Hypotheses 1.a, 1.b, 1.c, 1.d and 3 are supported and consistent before controlled by up-down market. The return variance of the first and second session in trading period when compared with the overnight return is not statistically significant in the down-market return. For additional consideration, hypotheses 1.c, 1.d and 3 contradict the previ-

Table 15a. Compare Return Variance of the Up-Down Market for Trading and Nontrading Periods

\begin{tabular}{|c|c|c|c|c|}
\hline & $\mathbf{R}_{1}$ & $\mathbf{R}_{2}$ & $\mathbf{R}_{3}$ & $\mathbf{R}_{4}$ \\
\hline Ratio & $0.7322 * * *$ & 0.9032 & $0.8940 * *$ & 1.1816 \\
\hline F-Levene & 11.2439 & 0.3739 & 5.6071 & 0.2734 \\
\hline
\end{tabular}

Note:

*significant at level 10,00\%; **significant al level 5,00\%; ***significant at level 1,00\% $\mathrm{R}_{1}$ : Return for night session in nontrading period; $\mathrm{R}_{2}$ : Return for first session in trading period; $R_{3}$ : Return for lunch break session in nontrading period; $R_{4}$ : Return for second session in trading period

Table 15b. Compare Return Variance of the Up-Down Market for Daily Return

\begin{tabular}{|c|c|c|c|c|}
\hline & $\mathrm{O}_{1}$ & $\mathrm{C}_{1}$ & $\mathbf{O}_{2}$ & $\mathrm{C}_{2}$ \\
\hline Ratio & $0.9897 * *$ & 0.9761 & 0.9829 & 0.8579 \\
\hline F-Levene & 4.9427 & 1.4650 & 1.5573 & 0.3713 \\
\hline
\end{tabular}

Note:

*significant at level 10,00\%; ** significant al level 5,00\%; ***significant at level 1,00\% $\mathrm{O}_{1}$ : Return for opening price in the first session in trading period to opening price of the previous day; $\mathrm{C}_{1}$ : Return for closing price in the first session in trading period to closing price of the previous day return; $\mathrm{O}_{2}$ : Return for opening price in the second session of trading period to opening price of the previous day; $\mathrm{O}_{2}$ : Return for closing price in the second session to closing price of the previous day return 
Sumiyana-Behavior of Stock Price Variability over Trading and Nontrading Periods, and...

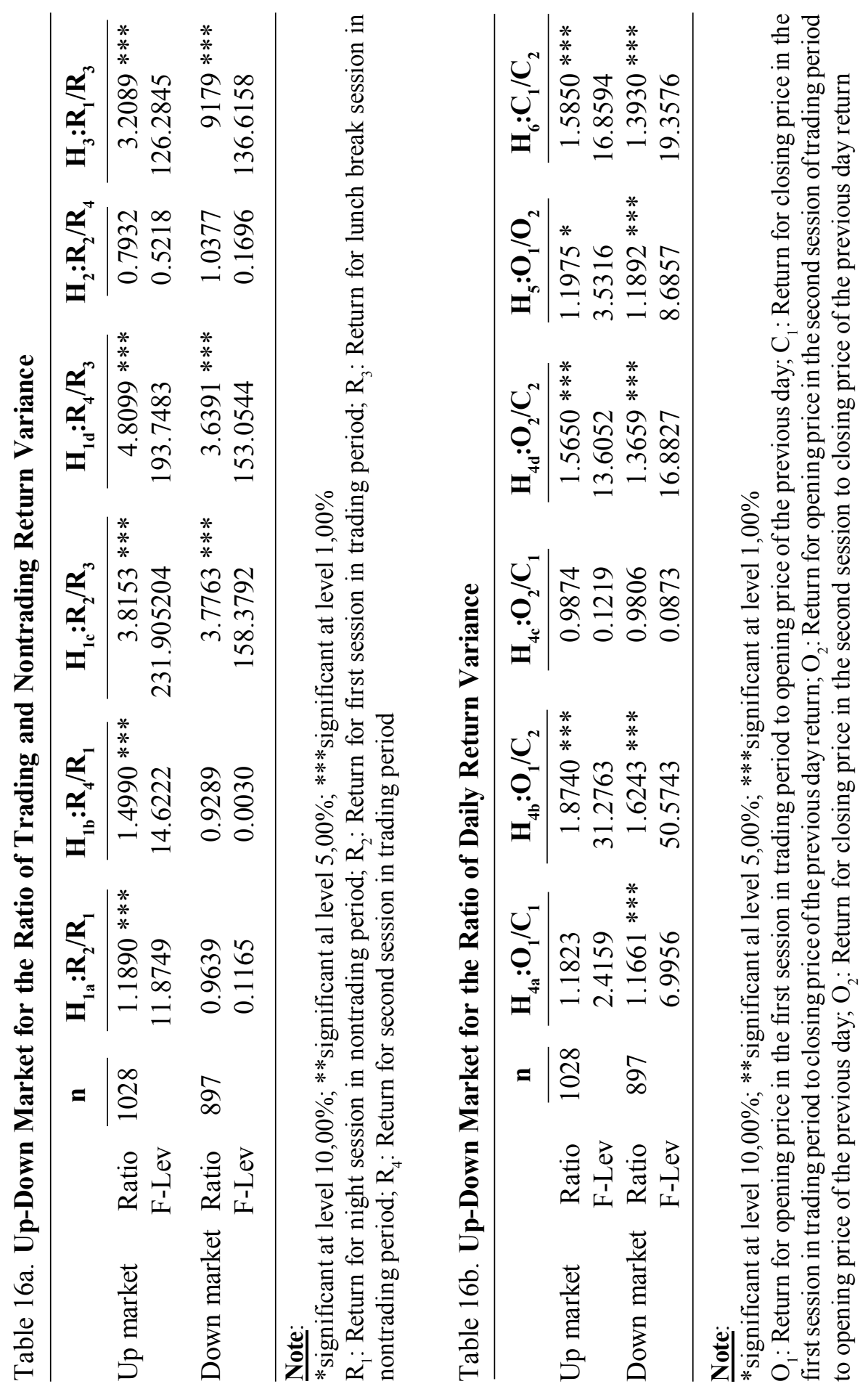


ous empirical studies, because both of the up-market and down-market return are statistically significant. In addition, hypothesis 2 is not supported. The complete result is exhibited in Table 16a.

Using the same procedure, return variance difference for the daily return controlled by up-down market is statistically significant. The differences occurred are related to the opening or closing price in trading period. This study concluded that hypotheses 4.a, 4.b, 4.d, 5 and 6 are supported and inconsistent with the one before it is controlled by up-down market. This study contradicts previous empirical studies which conclude that return volatility occurs in down-market condition. However, the result for hypothesis 4 .a which is not statistically significant in the up-market condition is an exception. In addition, hypothesis 4.c is statistically insignificant when the denominators are the return for the closing price of first session in trading period $\left(\mathrm{C}_{1}\right)$. The complete result is exhibited in Table 16b.

\section{Analysis}

The findings are about the consistency of the hypotheses testing. The consistency is tested by comparing between the test result in this study, empirical concepts and hypotheses developed by the previous studies. The findings are presented in the following discussions.

Previous studies, concepts and hypotheses conclude that the highest return variance is located in the opening and closing return in trading period (Wood et al. 1985). Ko et al. (1995) argue that the first session in trading period is more volatile than the second session in trading period. Guner and Onder (2001) conclude that the difference in overnight session in nontrading period return is caused by the longer interval than the lunch break session. Furthermore, the volatility of lunch break session return is the lowest because of the little information that investors got (Amihud and Mendelson 1991). This study results are consistently investigated with the previous empirical studies. The available evidences prove that the return variance difference is statistically significant.

Related to the daily return, Amihud and Mendelson (1987) argue that there is a significant difference in the opening and closing price volatility in NYSE. Guner and Onder (2000) conclude that return volatility in the closing price of the second session in trading period is the lowest among other returns. It has been investigated thoroughly and consistently that the closing price in the second session of trading period contributes to the daily return volatility.

The two paragraphs above are reexamined in order to investigate consistency internally. The reexamination was conducted by the variable controls stated in the following paragraphs.

1. Controlling based on size. Guner and Onder (2001) conclude that the ratio of return variance in trading 
Sumiyana - Behavior of Stock Price Variability over Trading and Nontrading Periods, and...

and nontrading periods has a linear relationship with the size of the firms. Chan and Nai (1991) argue that small-sized firms have bigger risks than big-sized firms. Elfakhani (1991) concludes that variability tends to happen more frequently in small-sized firms because of the lack of information. Small-sized firms should present higher volatility than the big ones. It has been invalidly investigated that small-sized firms have very big return variance.

2. Controlling based on the trading volume. Easley and O'Hara (1987) conclude that high trading volume occurs if the price level moves too high. They also argue that big return volatility occurs in the big trading volume because there is private information. Admati and Pflederer (1988) conclude that return volatility is high in trading volume of trading period. These previous researchers' concepts are reexamined invalidly by this study. Although there is a significant return variance difference, but the higher return variance occurs in both small and big trading volume. All of the test results, when controlled by trading volume, the linear return volatility and trading volume, are invalid.

\section{Controlling based on bid-ask} spread. Mcnish and Wood (1992) conclude that there is a linear relationship between return volatility and bid-ask spread. Bid-ask spread is directly and significantly related to the amount of information arrives in the market which makes the volatility level higher. Branch and Freed (1977) also argue that bid-ask spread increases when the return volatility increases too. The previous researchers' concepts are invalidly investigated by this study. Although there is a significant difference return variance, but the analysis demonstrates that the return variance is higher in the smaller bid-ask spread. All of the test results, when controlled by bid-ask spread, the linear relation of return volatility and bidask spread, is invalid.

4. Controlling based on up-down market. Chang et al. (1993) conclude that the ratio between opening price return variance and closing price return variance are sensitive to the market condition. The previous theoretical concepts are invalidly investigated by this study. The analysis has significantly or has insignificantly return variance difference, when the market is up with bigger return variance and when market is down with smaller return variance. From the test results, the first session of trading period $\left(\mathrm{R}_{1}\right)$ is examined to be significant but it contradicts the previous empirical concepts. Moreover, return variances for overnight session $\left(\mathrm{R}_{1}\right)$, lunch session $\left(\mathrm{R}_{3}\right)$ and open-to-open in the first trading session $\left(\mathrm{O}_{1}\right)$ are statistically significant, but this study contradicts the previous studies. 
Gadjah Mada International Journal of Business, September - December 2007, Vol. 9, No. 3

Conclusions and Limitations

Conclusions inferred from this study are as follows. The highest return variance occurs in the opening and closing of trading day return. The highest return in the opening price causes the return volatility level in the first session of trading period to be more volatile. The difference in the overnight session of trading period return is caused by the longer interval than the lunch break session. The short interval of lunch break session makes the return volatility be the lowest because of the investors get less private information (owned by only a few investors). This theoretical concept is supported.

Related to daily return volatility, there is significant difference in opening and closing price volatility. Return volatility in the closing price of the second session in both trading periods are the lowest among other period returns. It is validly supported that the closing price of the second session in trading period triggers the daily return volatility.

Controlling based on size concludes that the ratio of trading and nontrading return variance has a linear relation with the size of the firms, and the small-sized firms have bigger risks than the big ones. It is not valid that both small-sized and big-sized firms variance return are different significantly. Controlling based on the trading volume states that bigger return volatility occurs in big trading volume which is supported by private informa- tion and the return volatility in high trading volume in trading period. This concept is not valid, because the investigation is reversed for the trading and nontrading return variance and daily return variance.

Controlling based on bid-ask spread suggests that the linear relationship between return volatility and bid-ask spread increases when the return volatility increases too. The investigation proves that the previous theoretical concept is not valid; because the result demonstrates the higher return variance occurs in smaller bidask spread for trading and nontrading return variance or daily return variance. Controlling based on up-down market argues that the ratio of opening price return variance and closing price return variance are sensitive to the market condition. The previous empirical concepts is proved not valid by this study, in which the investigation shows that there is no significant return variance difference that when the market is up the return variance is bigger. Furthermore, when the market is down, the return variance is smaller.

After controlling return variances is employed by using size, trading volume, bid-ask spreads and up-down market, this study suggested that there is no trading pattern in Indonesia Stock Exchange. This conclusion depends upon the assumption that size, trading volume, bid-ask spreads and up-down market hypotheses are valid. Otherwise, this conclusion is correct because of the emerging market status of the Indonesia Stock Exchange. 
Sumiyana-Behavior of Stock Price Variability over Trading and Nontrading Periods, and...

This study has some limitations that can weaken the validity of this study. The limitations are firstly, the variable of trading transaction volume and bid-ask spread uses day to day data. It is better to use trading session rather than session data as variable. The reason is that trading volume and bid-ask spread are different for each session.

Secondly, trading period return only uses opening and closing price, although there is a possibility that instability might occur in the middle of the interval. This price movement is not detected in the design of this study. The subsequent studies can use the intraday data to investigate the return volatility in trading period. It means that the return volatility in trading period is not the true proxies by using opening and closing price in the first and second session in trading periods. Thirdly, this study only uses all stocks included in LQ 45 category. It means that it only describes the condition of highly frequent traded stocks.

\section{References}

Admati, A., and P. Pflederer. 1988. A theory of intraday patterns: Volume and price variability. The Review of Financial Studies 1 (1): 3-40.

Amihud, Y., and H. Mendelson. 1986. Asset pricing and the bid-ask spread. Journal of Financial Economics 17: 223-249.

1987. Trading mechanism and stock return: An empirical investigations. Journal of Finance 42: 533-53.

1991. Volatility, efficiency and trading: Evidence from the Japanese Stock Market. Journal of Finance 46: 369-89.

Balduzzi, P., E. J. Elton, and T. C. Green. 2001. Economic news and bond prices: Evidence from the US treasury market. Journal of Financial and Quantitative Analysis 36 (4): 523-543.

Bery, T., D., and K. M. Howe. 1994. Public information arrival. Journal of Finance 49: 1331-1347.

Blume, L., D. Easley, and O'Hara. 1994. Market statistics and technical analysis: The role of volume. Journal of Finance 49 (1): 153-181.

Branch, B., and W. Freed. 1977. Bid-ask spreads on the Amex and the big board. Journal of Finance 32 (1) (March): 159-163.

Brown, M., B., and A. B. Forsythe. 1974. Robust tests for the equality of variances. Journal of the American Statistical Association 69 (346): 364-367.

Chan, K.C., W. G. Christie., and P. H. Schultz. 1995. Market structure and the intraday pattern of bid-ask spreads for NASDAQ Securities. Journal of Business 68 (1): 3560. 
Gadjah Mada International Journal of Business, September - December 2007, Vol. 9, No. 3

Chan, H., and F. C. Nai, 1991. Structural and return characteristics of small and large firms. Journal of Finance 46 (4): 1467-1484.

Chang, R. P., T. H. Hsu, N. K. Huang, and S. G. Rhe. 1999. The effect of trading methods on volatility and liquidity: Evidence from Taiwan Stock Exchange. Journal of Business Finance and Accounting 26(1): 137-170.

Chelley, P., and Steeley. 2001. Opening returns, noise and overreaction. Journal of Financial Research 24(4): 513-521.

Cheung, Y. L., 1995. Intraday return and the day end effect: Evidence from the Hong Kong equity market. Journal of Business Finance and Accounting 22 (7): 10231034.

Copeland, T., E., and D. Galai. 1983. Information effects on the bid-ask spread. Journal of Finance 38 (5): 1457-1469.

Easley, D., and O'Hara, 1987. Price, trade size and information in securities markets. Journal of Financial Economics 19: 69-90.

Elfakhani, S. 1991. Portfolio performance and the interaction between systematic risk, firm size and price-earning ratio: The Canadian evidence. Review of Financial Economics 51-69.

Elton, E. J., M. J. Gruber, D. Argawal, and C. Mann. 2001. Explaining the rate spread on corporate bonds. Journal of Finance 56 (1) February: 247-277.

Fama, E. F. 1970. Efficient capital market: A review of theory and empirical work. Journal of Finance 25: 387-417.

Fama, E. F.. 1991. Efficient Capital Markets II. Journal of Finance 46 (51): 575-617.

Fama, E. F., and French. 1992. The cross section of expected return. Journal of Finance 47: 427-465.

French, K. R., and R. Roll. 1986. Stock price variances: The arrival of information and the reaction traders. Journal of Financial Economics 17: 5-26.

Frino, A., and A. Hill. 2001. Intraday futures market behavior around major scheduled macroeconomics announcements: Australian evidence. Journal of Banking and Finance 25: 1319-1337.

Glosten, L., R., and L. E. Haris. 1988. Estimating the component of the bid-ask spread. Journal of Financial Economics 21: 123-142.

Gomez, X. G., J. Hodoshima, and M. Kunimura. 1998. Does size really matter in Japan? Association for Investment Management and Research (Nov./Dec.): 22-34

Grundy, B., D., and Y. Kim. 2002. Stock market volatility in a heterogeneous information economy. Journal of Financial and Quantitative Analysis 37 (1): 1-27.

Guner, N., and Z. Onder. 2002. Information and volatility: Evidence from an emerging market. Emerging Markets Finance and Trade 36 (6): 26-46.

Hasbrook, J. 1988. Trades, quotes, inventories and information. Journal of Financial Economics 30: 99-134. 
Sumiyana-Behavior of Stock Price Variability over Trading and Nontrading Periods, and...

Huang, Y., S., D. Y. Liu, and T. W. Fu. 2000. Stock price behavior over trading and nontrading periods: Evidence from the Taiwan stock exchange. Journal Business and Financial Accounting 27 (5): 575-602.

Ito, T., R. K. Lyons, and M. T. Melvin. 1998. Is there private information in the FX Market? The Tokyo experiment. Journal of Finance 53 (3): 1111-1130.

Karpoff, J. M. 1987. The relation between price changes and trading volume: Survey. Journal of Financial and Quantitative Analysis 18: 109-126.

Ko, K, S. Lee and J. Chung. 1995. Volatility, efficiency and trading: Further evidence. Journal of International Financial Management and Accounting 6 (1): 26-42.

Kyle, A. S. 1985. Continuous Auctions and Insider Trading. Econometrics 53 (6): 13151335.

Lakonishok, J., and E. Maberly. 1990. The Weekend Effect: Trading Patterns of Individual and Institutional Investors. Journal of Finance 45: 231-243.

Lam, P. H. L., and W. H. S. Tong. 1999. Interdaily volatility in a continuous Order Driven Market. Journal of Business Finance and Accounting 26 (7): 1013-1036.

Mcnish, T. H., and R. A. Wood. 1992. An analysis of intraday patterns in bid/ask spread for NYSE Stocks. Journal of Finance 47 (2): 753-764.

Nofsinger, J.R. 2001. The impact of public information on investors. Journal of Banking and Finance 25: 1339-1366.

Odean, T. 1998. Volume, volatility, price and profit when all traders are above average. Journal of Finance 53 (6): 1887-1934.

Oldfield, G. Jr., and R. J. Rogalski. 1980. A theory of common stock return over trading and nontrading periods. Journal of Finance 35: 729-51.

Pritamani, M., and V. Singal. 2001. Return predictability following large prices changes and information releases. Journal of Banking and Finance 25: 631-656.

Rogalski, R. J. 1984. New findings regarding day of the week return over trading and nontrading periods: A note. Journal of Finance 34 (5): 1603-1614.

Stoll, H., and R. Whaley. 1990. Stock market structure and volatility. Reviewof Financial Journal 5: 231-58

Stoll, H. R., 1989. Inferring the component of the bid-ask spread: Theory and empirical test. Journal of Finance 44: 115-134.

Suhaibani, M. A., and L. Kryzanowski. 2000. The information content of orders on the Saudi Stock Market. Journal of Financial Research 23 (2): 145-156.

Wood, R. A., T. H. Mcnish, and J. K. Ord. 1985. An investigation of transaction data for NYSE Stock. Journal of Finance 40 (3): 739-741. 